\title{
抗生物質の自己耐性と生合成調節機構の遺伝生化学
}

\author{
小河原宏 \\ 明治薬科大学生化学教室, $=204-8588$ 秋津市野塩 2-522-1
}

\section{Genetic and Biochemical Studies on the Regulatory Mechanism of the Self-Resistance and Biosynthesis of Antibiotics}

\author{
Hiroshi OGaWARA \\ Department of Biochemistry, Meiji Pharmaceutical University, \\ 2-522-1, Noshio, Kiyose, Tokyo 204-8588, Japan
}

(Received December 5, 2000)

\begin{abstract}
The following topics are described: 1 . chemistry of $\beta$-lactamases; $2 . \beta$-lactamases from Streptomyces including distribution of $\beta$-lactamases in actinobacteria, properties of $\beta$-lactamases from Streptomyces, cloning and regulatory mechanism of expression of $\beta$-lactamase genes from Streptomyces and evolution and classification of $\beta$-lactamases in general; 3. penicillin-binding proteins from Streptomyces including $\beta$-lactam-producing- and non-producing strains and 4. eukaryotic-type protein kinases from Streptomyces including cloning of the genes and evolution and classification of eukaryotic-type protein kinases in general.
\end{abstract}

Key words_ $\beta$-lactamases; Streptomyces; eukaryotic-type protein kinases; penicillin-binding proteins; gene; drug resistance

\section{1. はじめに}

1970 年前後は新抗生物質の探索もなかなか渉ら ず，一方では抗生物質耐性が話題になり始めた時期 である. 私が以前所属していた国立予防衛生研究所 （予研，現国立感染症研究所）抗生物質部では， $\beta$ ラクタム剤に対するその当時主要な耐性機構であっ た $\beta$-ラクタマーゼに対する阻害剂を探索してお り，私も関与していた. ${ }^{1)}$ ちょうどその頃アメリカ のグループにより放線菌から始めて 7 位にメトキシ 基を有するセファマイシン系の $\beta$-ラクタム抗生物 質が単離されセンセーションを起こしていた. ${ }^{2)}$ た一方で抗生物質耐性機構も盛んに研究され始めて おり，予研の鈴木，岡本などによりアミノグリコシ ド系抗生物質でのアセチル化, リン酸化, AMP 化 やクロラムフェニコールのアセチル化などによる不 活性化が始めて明らかにされていた。このような背 景から，私は病原菌ではなく生産菌の 1 つである放 線菌における $\beta$-ラク夕ムに対する自己耐性につい て取り上げることにした訳である。これが私の $\beta$ ラクタム/ $\beta$-ラクタマーゼ/放線菌とのつき合いの
始まりであり，その当時はこのように長くつき合う とは予想もしなかったことである。 今から思えば長 期間の研究とは大体このようにして始まるのではな いかと思う。

\section{2. $\beta$-ラクタマーゼの化学}

$\beta$-ラクタマーゼ阻害剤の探索に用いた患者由来 多剂耐性大腸菌の $\beta$-ラクタマーゼの活性中心につ いての化学的な知見を得るために，当時はまだX 線解析の結果が出ていない時であったため, 化学試 薬を用い解析した。 その過程で新しいアフィニテ イーラベル試薬を開発でき，その方法が Methods in Enzymology に掲載されることになった. ${ }^{3)}$ すな わち, ベンジルペニシリンイソチオシアネートであ る. その後も色々の試薬を合成したが, 光アフィニ ティーラベル試薬は結局使わずにお蔵に（今でもフ リーザーに）眠ったままになってしまった.

\section{3. 放線菌の $\beta$-ラクタマーゼ}

3-1. $\boldsymbol{\beta}$-ラクタマーゼの分布＼cjkstart主な薬剤耐性機 構として薬剤の分解を含む化学修飾, 標的の変化, 薬剂透過性の変化の 3 つが古くから知られている. 
そこで放線菌における $\beta$-ラクタム自己耐性の第 1 の候補として $\beta$-ラクタムの化学修飾すなわち $\beta$-ラ クタマーゼについて検討した。そのためまず土壌か ら単離され Streptomyces として同定された菌 100 株につき $\beta$-ラクタマーゼを生産しているかどうか を液体培養上清で調べた. ${ }^{4)}$ その結果, 約半数の菌 で 2.3 単位 $/ \mathrm{ml}$ 以上の, 残りの半数の菌で 1.4 単位 $/ \mathrm{ml}$ 以下の $\beta$-ラクタマーゼを生産していた，と言 うことはStreptomyces 属放線菌の大部分が $\beta$-ラク タマーゼを構成的に菌体外に分泌していることを示 していた. しかもこれら生産菌のベンジルペニシリ ンに対する最小阻止濃度との比較から, $\beta$-ラク夕 マーゼの生産はベンジルペニシリンに対する耐性と は直接関係していないことも明らかとなった。一般 に黄色ブドウ球菌や枯草菌などのグラム陽性菌はぺ ニシリンに対して極めて高い感受性を示すが,

Streptomyces 属放線菌はグラム陽性細菌であるに もかかわらずベンジルペニシリンに対する最小阻止 濃度が $3.1-25 \mu \mathrm{g} / \mathrm{ml}$ と感受性が低いことも判明し た. 生産の時間経過から考えて二次代謝産物として 生産されしかもぺニシリンに対する耐性とは直接関 係しないで生産されるとなると， $\beta$-ラクタマーゼ は放線菌のような非病原菌にとつて一体何の目的が あって生産されるのかという疑問が生じてくる.ま た病原菌による $\beta$-ラクタマーゼの生産は, ペニシ リンが利用されるようになって産生する病原菌の種 類が拡大すると同時に産生量も増大してきている.

$\beta$-ラクタム抗生物質を生産することが明らかにさ れた Streptomyces 属放線菌では果たしてどうなの かと言うことも, 病原菌の $\beta$-ラクタマーゼとの関 係あるいは由来を考えたとき重要な問題である，そ こで予研の歌原良三博士と科研化学の清野昭雄博士 のご厚意により，次に土壌から新たに分離した Streptomyces 属放線菌 100 株と，いまだほとんど ペニシリンや他の抗生物質に曝される機会の少なか つたであろう約 30 年ほど前に土壌から分離し実験 室に保管されていた Streptomyces 属放線菌 99 株に つき $\beta$-ラクタマーゼの生産性，もし生産されるな らばその性質がどのように変化したかを比較検討し た. ${ }^{5)}$ その結果, Table 1 に示すように生産する放線 菌の割合も生産する量も特に両者で有意の差が見ら れないことが明らかとなつた。ささに生産される $\beta$ -ラクタマーゼの等電点, 分子量, 基質特異性など
Table 1. Production of $\beta$-Lactamases in Streptomyces

\begin{tabular}{ccc}
\hline \hline \multirow{2}{*}{$\begin{array}{c}\text { Enzymatic activity } \\
(\text { units } / \text { ml })\end{array}$} & \multicolumn{2}{c}{ No. of strains } \\
\cline { 2 - 3 } & New & Old \\
\hline 0 & 28 & 24 \\
$<1$ & 19 & 34 \\
$2-10$ & 24 & 15 \\
$11-50$ & 24 & 15 \\
$>50$ & 5 & 11 \\
\hline Total & 100 & 99 \\
\hline
\end{tabular}

の諸性質も両者で差が見られなかった．このことは， Streptomyces 属放線菌は病原菌と異なりペニシリ ンの導入によって $\beta$-ラクタマーゼの生産性, その 物理化学的諸性質がほとんど影響を受けないことを 示し， $\beta$-ラクタマーゼの生理的役割や進化を考え る上で非常に示唆に富む結果を与えてくれた.

一方, Streptomyces 属放線菌は $\beta$-ラク夕ム抗生 物質を生産するが，いわゆる稀少放線菌は $\beta$-ラク タムをほとんど生産しないことが古くから知られて いた（三共(侏の岡崎尚夫博士からの私信）。そこで 中瀬崇博士らとの共同研究で理研に保存されている Table 2 に示す 36 属 127 株の稀少放線菌につき, $\beta$ ーラクタマーゼを生産するかどうかを液体培養によ り調べた. ${ }^{6)}$ 一般に Streptomyces 属以外の稀少放線 菌の生育速度は極めて遅く, 7 日おきに 30 日以上 にわたり測定した. その結果をベンジルペニシリン に対する最小阻止濃度と共に Table 3 に示した。す なわち, $\beta$-ラクタマーゼを検出できた菌株は 36 属 127 株のうち Aeromicrobium erythreum JCM8359, Actinomadura cremea subsp. rifamicini JCM3309, Saccharomonospora azurea JCM7551, Saccharothrix flava JCM3296, Saccharothrix aerocolonigenes subsp. aerocolonigenes JCM4150, Saccharothrix waywayandensis JCM9114の 4 属 6 菌株にすぎず, Saccharothrix 属以外はほとんどの菌株が $\beta$-ラク夕 マーゼを生産しないことが判明した。しかも $\beta$-ラ クタマーゼの生産とベンジルペニシリンに対する最 小阻止濃度の間にはStreptomyces 属放線菌のとき 同様相関性は見られなかった。 さらに Fig. 1 に示 すように, これら稀少放線菌の $16 \mathrm{~S}$ rRNAに基づ く系統関係と $\beta$-ラクタマーゼ生産菌の系統関係は 全く相関関係が見られなかった。Saccharothrix 属 放線菌が $\beta$-ラクタムを生産するかどうかは現在不 
Table 2. List of Actinomycete Strains Used in This Paper

\begin{tabular}{|c|c|c|c|c|c|c|c|}
\hline Species & $\begin{array}{l}\text { JCM } \\
\text { No. }\end{array}$ & Species & $\begin{array}{l}\text { JCM } \\
\text { No. }\end{array}$ & Species & $\begin{array}{l}\text { JCM } \\
\text { No. }\end{array}$ & Species & $\begin{array}{l}\text { JCM } \\
\text { No. }\end{array}$ \\
\hline Actinokineospora & & A. fastidiosa & 3276 & Kibdelosporangium & & Rhodococcus & \\
\hline A. diospyrosa & 9921 & A. mediterranei & 4789 & $K$. aridum subsp. & 7912 & R. equi & 1311 \\
\hline A. globicatena & 9922 & A. methanolica & 8087 & & & R. eryth & 3201 \\
\hline Actinomadura & & $\begin{array}{l}\text { A. orientalis subsp. } \\
\text { lurida }\end{array}$ & 3141 & $\begin{array}{l}\text { K. aridum subsp. } \\
\text { largum }\end{array}$ & 9107 & R. rhodochrous & 3202 \\
\hline A. atramentaria & 6250 & & & Kineosporia & & Saccharomonospora & \\
\hline A. aurantiaca & 8201 & $\begin{array}{l}\text { A. orientalis subsp. } \\
\text { Orientalis }\end{array}$ & 4600 & K. aurantiaca & 3230 & S. azurea & 7551 \\
\hline A. citrea & 3295 & Arthrobacter & & Microbispora & & S. cyanea & 7552 \\
\hline A. coerulea & 3320 & A. globiformis & 1332 & M. rosea subsp & 3006 & S. glauca & 7444 \\
\hline $\begin{array}{l}\text { A. cremea subsp. } \\
\text { cremea }\end{array}$ & 3308 & A. polychromogenes & 2523 & M. amethystogenes & 3021 & Saccharopolyspora & \\
\hline A. cremea subsp. & 3309 & Brevibacterium & & Micromonospora & & & 4026 \\
\hline rifamicini & & B. linens & 1327 & M. carbonacea subsp. & 3139 & & 9687 \\
\hline A. fulvescens & 6833 & B. linens & 2590 & carbonacea & & S. hordei & 8090 \\
\hline A. hibisca & 9627 & Catellatospora & & M. charcea & 3031 & S. taberi & 9383 \\
\hline A. kilaniata & 3306 & C. citrea subsp. citrea & 7542 & M. halophytic & 3125 & Saccharothrix & \\
\hline A. libanotica & 3284 & C. ferruginea & 7544 & $\begin{array}{l}\text { haloph } \\
\text { M. oli }\end{array}$ & 7348 & $\begin{array}{l}\text { S. aerocolonigenes } \\
\text { subsp. aerocolonigenes }\end{array}$ & 4150 \\
\hline A. luteofluorescens & 4203 & C. matsumotoense & 9104 & Microtetraspora & & S. aerocolonigenes & 9734 \\
\hline A. rugatobispora & 3366 & C. tsunoense & 9105 & M. fusca & 3183 & & \\
\hline A. umbrina & 6837 & Catenuloplanes & & & 3300 & S. austrc & 3370 \\
\hline A. verrucosospora & 3147 & C. atrovinosus & 9535 & & 3149 & S. coeru & 3313 \\
\hline A. vinacea & 3325 & C. japonicus & 9106 & Nocar & 314 & violacea & 9110 \\
\hline A. yumaensis & 3369 & Cellulomonas & & N. & 3185 & S. cryophylis & 9111 \\
\hline Actinoplanes & & C. fimi & 1341 & $N . l$ & 3358 & S. espanaensis & 9112 \\
\hline A. brasiliensis & 3196 & Corynebacterium & & intarum & 9626 & S. flava & 3296 \\
\hline A. consettensis & 7624 & C. aquaticum & 1368 & $N$ & 10369 & S. longispora & 3314 \\
\hline A. deccanensis & 3247 & Couchioplanes & & N. simplex & 1363 & $\begin{array}{l}\text { S. mutabilis subsp. } \\
\text { capreolus }\end{array}$ & 4248 \\
\hline A. derwentensis & 7556 & $\begin{array}{l}\text { C. caeruleus subsp. } \\
\text { azureus }\end{array}$ & 3246 & Nocardiopsis & & & 3380 \\
\hline A. durhamensis & 7625 & Curtobacterium & & N. alba & 9419 & & \\
\hline $\begin{array}{l}\text { A. ferru } \\
\text { A. italic }\end{array}$ & 3277 & C. citr & 1345 & N. dassonvillei & 7437 & S. syringae & 6844 \\
\hline A. $l t$ & 945 & C. lute & 1480 & N. prasina & 3336 & S. texasensis & 9113 \\
\hline A. minuti & $\begin{array}{l}9458 \\
7626\end{array}$ & C. pusillum & 1350 & Nonomuria & & S. waywayandensis & 9114 \\
\hline $\begin{array}{l}\text { A. pallerronil } \\
\text { A. philippinensis }\end{array}$ & $\begin{array}{l}7020 \\
3001\end{array}$ & Dactylosporangium & & N. roseola & 3323 & Streptosporangium & \\
\hline $\begin{array}{l}\text { A. philppinensis } \\
\text { A. rectilineatus }\end{array}$ & 319 & D. aurantiacum & 3083 & N. spiralis & 3286 & S. album & 3025 \\
\hline A. utahensis & 3122 & D. roseum & 3364 & Planobispora & & S. amethys & 3026 \\
\hline Actinosynnema & & D. thailandense & 3084 & P. longispora & 3092 & & \\
\hline A. mirum & 3225 & D. vinaceum & 3307 & P. rosea & 3166 & $\begin{array}{l}\text { S. longlsporum } \\
\text { S. nondiastaticum }\end{array}$ & $\begin{array}{l}3106 \\
3114\end{array}$ \\
\hline $\begin{array}{l}\text { A. pretiosum subsp. } \\
\text { auranticum }\end{array}$ & 7343 & $\begin{array}{l}\text { Geodermatophilus } \\
\text { G. obscurus }\end{array}$ & 3152 & $\begin{array}{l}P . \text { parontospora } \\
\text { subsp. antibiotica }\end{array}$ & 3094 & $\begin{array}{l}\text { S. pseudovulgare } \\
\text { S. roseum }\end{array}$ & $\begin{array}{l}3115 \\
3005\end{array}$ \\
\hline $\begin{array}{l}\text { A. pretiosum subsp. } \\
\text { pretiosum }\end{array}$ & 7344 & $\begin{array}{l}\text { Glycomyces } \\
\text { G. harbinensis }\end{array}$ & 7347 & $\begin{array}{l}\text { P. parontospora } \\
\text { subsp. parontospora }\end{array}$ & 3093 & $\begin{array}{l}\text { S. violaceochromogenes } \\
\text { S. vulgare }\end{array}$ & $\begin{array}{l}3281 \\
3028\end{array}$ \\
\hline Aeromicrobium & & G. rutgersensis & 6238 & $P$. venezuelensis & 3167 & S. vulgare & 3028 \\
\hline A. erythreum & 8359 & Gordonia & & Planotetraspora & & & \\
\hline A. fastidiosum & 8088 & G. terrae & 3229 & P. mira & 9131 & & \\
\hline Amycolatopsis & & Herbidospora & & Prauserella & & & \\
\hline A. azurea & 3275 & H. cretacea & 8553 & P. rogosa & 9736 & & \\
\hline
\end{tabular}

明であるが，以上の結果は， $\beta$-ラクタマーゼの生 産と $\beta$-ラクタム抗生物質の生産とは何らかの関係 があるらしいことを示している，以上の結果を含め
現在までの知見を総合すると， $\beta$-ラクタマーゼが 生産菌の $\beta$-ラク夕ム抗生物質に対する自己耐性や 生合成（化学反応それ自身）に関与しているとは到 
Table 3. Production of $\beta$-Lactamases and MICs in Actinobacteria

\begin{tabular}{lcrr}
\hline \hline & $\begin{array}{c}\beta \text {-Lactamase activity } \\
(\text { units } / \mathrm{ml})\end{array}$ & $\begin{array}{c}\text { Culture time } \\
(\text { Day })\end{array}$ & $\begin{array}{c}\text { MICs } \\
(\mu \mathrm{g} / \mathrm{ml})\end{array}$ \\
\hline A. erythreum JCM8359 & 0.43 & 3 & 50 \\
A. cremea subsp. rifamicini JCM3309 & 0.16 & $10-40$ & 200 \\
S. azurea JCM7551 & 0.11 & 37 & 50 \\
S. flava JCM3296 & 1.04 & 7 & 500 \\
S. aerocolonigenes subsp. aerocolonigenes JCM4150 & 0.92 & 7 & 200 \\
S. waywayandensis JCM9114 & 0.16 & 8 & 50 \\
S. cacaoi subsp. cacaoi JCM4352 (medium E) & 1.59 & 3 & 100 \\
S. cacaoi subsp. cacaoi JCM4352 (medium R) & 1.51 & 3 & 100 \\
\hline
\end{tabular}

Table 4. Substrate Specificity of $\beta$-Lactamase from Streptomyces cacaoi

\begin{tabular}{lccc}
\hline \hline & $\begin{array}{c}\text { Relative hydrolysis rate } \\
\text { (benzylpenicillin=100) }\end{array}$ & $\begin{array}{c}\mathrm{K}_{\mathrm{m}} \\
(\mu \mathrm{M})\end{array}$ & $\begin{array}{c}\mathrm{V}_{\max } \\
\text { (benzylpenicillin = 100) }\end{array}$ \\
\hline Benzylpenicillin & 100 & 63.8 & 100 \\
Ampicillin & 38 & 43.6 & 96.3 \\
Cloxacillin & 38 & 87.5 & 128.8 \\
Methicillin & 73 & 131 & 147.5 \\
Carbenicillin & 66 & 65.1 & 69.3 \\
Cephaloridine & 3.1 & - & - \\
Cephalothin & 0.7 & - & - \\
Cephazoline & 2.1 & - & - \\
Cephalexin & 1.9 & - & - \\
Y-G19Z-G & 3.1 & - & \\
\hline
\end{tabular}

底考えられないが，一方でいくつかの細菌由来 $\beta-$ ラクタム抗生物質生合成遺伝子クラスター内に $\beta-$ ラクタマーゼ遺伝子が見い出だされており, $\beta$-ラ クタム抗生物質の生合成に何らかの関係があるある いはあったものと思われる. 他方, カビ由来の $\beta-$ ラクタム抗生物質生合成遺伝子クラスターの構成は 細菌由来のものと類似するが， $\beta$-ラクタマーゼ遺 伝子を含んでいない.このことからカビの $\beta$-ラク 夕厶抗生物質生合成遺伝子は細菌特に放線菌に由来 し, その後に $\beta$-ラクタマーゼ遺伝子は脱落したも のと考えられている. ${ }^{7}$

3-2. $\boldsymbol{\beta}$-ラクタマーゼの性質＼cjkstart前述したように, Streptomyces属放線菌は $\beta$-ラク夕ム抗生物質のほ かにクラブラン酸などの $\beta$-ラクタム骨格を有する $\beta$-ラクタマーゼ阻害剂を生産する。 すなわち放線 菌の中では $\beta$-ラクタム抗生物質 $/ \beta$-ラクタマーゼ阻 害剂, $\beta$-ラクタマーゼ, $\beta$-ラクタム抗生物質の標 的であるペニシリン結合タンパク質の 3 者あるいは 4 者が阻害剂, 基質, 酵素, 標的と言つた複雑な関 係にある. ${ }^{8)}$ 一方では病原菌 $\beta$-ラクタマーゼは放線
菌など $\beta$-ラクタムを生産する細菌の $\beta$-ラクタマー ゼに由来したとも考えられている. ${ }^{8)}$ そこでこれら 4 者の関係と $\beta$-ラクタマーゼの進化との関係を明 らかにする目的で, 2,3 の放線菌由来の $\beta$-ラク夕 マーゼを精製しその性質を調べた.

まず後に述べるペニシリン結合タンパク質との関 係から Streptomyces cacaoi KCCS0352 由来の $\beta$-ラ クタマーゼを精製した. ${ }^{9)}$ 一般的なタンパク質の精 製方法により精製した酵素は分子量 34,000 ; 等電 点 4.7 ; 至適 $\mathrm{pH} 6.5$ で, 比活性は 2,430 単位 $/ \mathrm{mg}$ 夕 ンパク質であり Bacillus cereus や Staphylococcus aureus などほかのグラム陽性菌由来の $\beta$-ラク夕 マーゼとほぼ同程度の比活性を示した. ベンジルペ ニシリンを最もよく加水分解するが, グラム陽性菌 の酵素としては珍しくクロキサシリンやメチシリン も相当程度加水分解した (Table 4)。阻害剤として はほかのペニシリナーゼと同様 N-ブロムコハク酸 イミドにより強く阻害され, 酵素活性へのトリプト ファンの関与が考えられた。 ベンジルペニシリンを 基質にすると $\mathrm{K}_{\mathrm{m}}$ 值は $\mathrm{pH}$ の減少と共に増加しその 


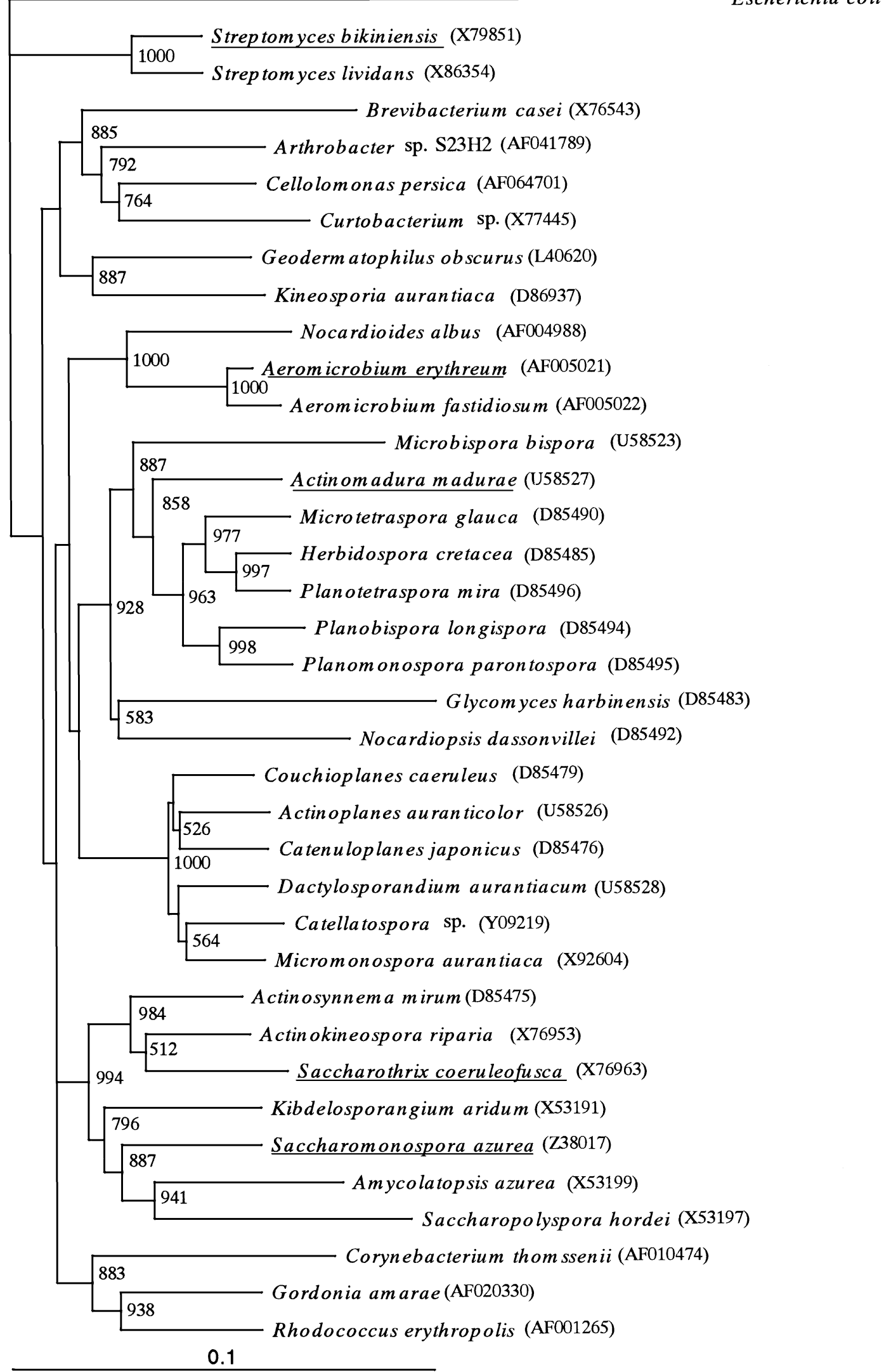

Fig. 1. Phylogenetic Tree Constructed on the Basis of Nucleotide Sequences of 16S rRNAs with Clustal $\mathrm{W}^{58)}$

The GenBank accession numbers are indicated in parentheses. The bootstrap probabilities are shown at the left. The bar represents 0.1 substitution per site. Escherichia coli was used as an outgroup. The genera of the ones that showed $\beta$-lactamase activity are underlined. 
$\mathrm{pK}_{\mathrm{a}}$ は 6.5-7.0であった。一方，クロキサシリン を基質にすると $\mathrm{K}_{\mathrm{m}}$ 值は $\mathrm{pH} 7.5$ で最小を示した. また $\mathrm{pH}$ と $\mathrm{V}_{\max }$ との関係を調べるとベンジルペニ シリンを基質にした場合はべル型の曲線を示すのに 対して，クロキサシリンを基質にすると $\mathrm{V}_{\max }$ はほ とんど変化しなかった．さらに加水分解速度の温度 による変化を両基質について測定するとやはり明確 な差異が認められた。 以上の結果から， S. cacaoi 由来の $\beta$-ラクタマーゼはベンジルペニシリンとク ロキサシリンに対して，両者はペニシリンであるに もかかわらず異なった挙動を示すことが明らかとな つた。

前述した放線菌由来 $\beta$-ラクタマーゼのスクリー ニングで, いくつかの $\beta$-ラクタマーゼは酸化還元 に関与しないにも関わらず，ブルーデキストランに 結合することが明らかとなっていた。 そこで次にそ の 1 つであるS. cellulosae KCCS0127 由来の $\beta$-ラ クタマーゼを精製した. ${ }^{10)}$ 硫酸アンモニウム分画, CM-セルローズカラムによる精製の後ブルーセフ アロースで精製すると，このアフィニティーカラム での収率が $50 \%$ 以上で約 6 倍精製され，ゲル電気 泳動などで均一な標品が得られた。一般にブルーデ キストランに結合するタンパク質はその立体構造の 類似性から“dinucleotide fold”と呼ばれる構造を 持ち, $\mathrm{NADP}^{+}, \mathrm{ATP}$ などのジヌクレオチドを結合

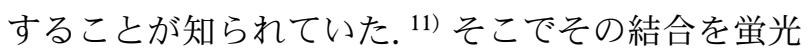
滴定で検討するとこの $\beta$-ラクタマーゼは $\mathrm{NAD}^{+}$, ATP とは相互作用が見られないが $\mathrm{NADP}^{+}$を滴下 すると蛍光強度が急速に低下し, 結合常数 $1.4 \times 10^{3}$ $\mathrm{M}^{-1}$ で結合することが判明した。 さらに $\mathrm{NADP}^{+}$ アガロースのカラムを通過させても $0.5 \mathrm{M} \mathrm{NaCl}$ 始めて溶出されることも示され，この $\beta$-ラク夕 マーゼが $\mathrm{NADP}^{+}$と相互作用することが明らかと なつた，後述するように，グラム陰性菌プラスミド 由来でクロキサシリンを加水分解する 2,3 の $\beta$-ラ クタマーゼ（いわゆる D 型 $\beta$-ラクタマーゼ） は, $\mathrm{NADP}^{+}$の結合性については検討されていないがブ ルーデキストランを結合することが知られており， これら一群の $\beta$-ラクタマーゼの由来/進化を考える 上で興味をそそる問題である，すなわち，現存する $\beta-$ $\beta$ タマーゼはデヒドロゲナーゼのような酸化 還元酵素からプロテアーゼ/ペプチダーゼ $(\beta-$ ラク タマーゼは広い意味でのペプチダーゼである）など
多種類の酵素が収斂進化した結果であるとも推定さ れた.

Streptomyces lavendulae KCCS0055 は異常な高 頻度でアルギニン要求変異株（アルギニノコハク酸 合成酵素遺伝子の欠失）を生成する.アルギニン要 求変異株は同時に気中菌糸, 胞子の生成を消失し, $\beta$-ラクタマーゼ生産が窒素カタボライト抑制/炭素

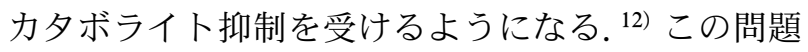
は抗生物質など二次代謝産物の産生上昇と窒素力夕 ボライト抑制/炭素カタボライト抑制との関係から 興味が持たれたが，未解決のまま放置されることに なってしまった，その当時, このアルギニン要求変 異株は他の放線菌でも高頻度に得られ，例えば $S$. lividans ではそれと同時にクロラムフェニコール感 受性/テトラサイクリン感受性株が得られており, ホットな話題の 1 つであった.この変異株は, 自然 突然変異でも極めて高い頻度で得られることからプ ラスミドが関与していると当時は考えたが, 放線菌 の染色体は大腸菌などと異なり直鎖状であること， 末端は繰り返し配列が多く DNA 断片が脱落しやす いことなどの現在の知見から考えれば，アルギニノ コハク酸合成酵素遺伝子及び窒素カタボライト抑制 /炭素カタボライト抑制関連遺伝子が繰り返し配列 と関係しているか染色体の末端に存在することで説 明されよう（この点はまだ証明されている訳ではな いが)。

3-3. 遺伝子のクローニングと遺伝子発現調節機 構 1987 年私たちはベルギーの Ghuysen 教授ら との共同研究として, S. lividans, pIJ702 の宿主一 ベクター系で, S. cacaoi KCCS0352より $\beta$-ラクタ マーゼの遺伝子を $19 \mathrm{~kb}$ の SphI 断片としてクロー ニングするのに成功した。 ${ }^{13)}$ 最大生産条件下で生育 した S. cacaoi のときよりこのプラスミドを含む $S$. lividans では約 30 倍の生産上昇が見られた。さら に興味あることに $19 \mathrm{~kb}$ の断片から $12.4 \mathrm{~kb}$ の部分 を除去すると $\beta$-ラクタマーゼの生産は著しく減少 し，さらに $1.8 \mathrm{~kb}$ までに縮めると $19 \mathrm{~kb}$ のさよ り約 $1 / 50$ 以下に減少した。このことはここにク ローニングした $\beta$-ラクタマーゼの構造遺伝子の上 流に何らかの酵素活性を上昇させる遺伝子が存在す ることを示唆している。そこでまず $\beta$-ラクタマー ゼ構造遺伝子領域のヌクレオチド配列を決定した. その結果, S. cacaoi の $\beta$-ラクタマーゼは 303 個の 
アミノ酸よりなり, Streptomyces albus G や Staphylococcus aureus 由来の $\beta$-ラクタマーゼと相同性の高 い $\mathrm{A}$ 型の $\beta$-ラクタマーゼと推定された. ${ }^{14)}$ さらに 上流領域を削り上流領域が $1.4 \mathrm{~kb}$ 存在した場合は 4 単位 $/ \mathrm{ml}$ に減少し, 上流 $0.4 \mathrm{~kb}$ では 1 単位 $/ \mathrm{ml}$ と最 初の $1 / 50$ に減少した。同様の酵素活性の減少は上 流領域にBamHI リンカーを挿入しても観察され， さらには上流と $\beta$-ラクタマーゼ構造遺伝子とを別 々のプラスミドに乗せ $S$. lividans に形質転換する ことによりこの上流領域の遺伝子は trans に作用す

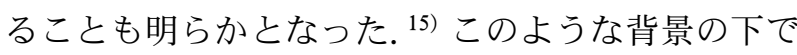
上流領域の約 $3 \mathrm{~kb}$ のヌクレオチド配列を決定し た. ${ }^{16)}$ 一般に放線菌の DNA は G+C 含量が約 72\% と高く，ヌクレオチド配列の決定はヒトDNA など に比較して極めて困難であるが，一方でこの性質を 利用して ORF (open reading frames) 領域を決定す るのは比較的簡単である（いわゆるFrame Analysis ${ }^{17)}$ の利用)。これにより決定したヌクレオ チド配列を解析すると，4つの ORF が見い出され た. Fig. 2 にこれら遺伝子と $\beta$-ラクタマーゼ構造 遺伝子との相対位置を示したが, ORF 1 (blaA, 2744-1764 位) と ORF 2（blaB, 1770-832 位, ORF 1 とは一部重複している), ORF 3 (552-154 位）は $\beta$-ラクタマーゼ構造遺伝子（bla ) と逆向き
に並んで存在し， ORF 4（50-778 位）は $\beta$-ラク タマーゼ構造遺伝子と同方向に離れて存在した.

BlaA は 326 個のアミノ酸よりなり，この領域に BamHI リンカーを挿入すると生産される酵素量は 約 1/50 に低下しアクチベーターをコードするもの と考えられた。実際 BlaA のアミノ酸配列を SEQHP, FASTAなどで相同検索すると, LysR, AmpR といつた調節タンパク質と高い相同性が見 られ，DNA との結合に必要なヘリックスーターンー ヘリックス構造を持ち，アクチベーターをコードし ていることが確認された。放線菌の遺伝子でよく見 られることであるが，S1 マッピングで転写開始点 を決めると転写開始点は BlaA の翻訳開始点と同じ か 1 塩基違いであることも判明した。 また BlaA と BlaB はオペロンとして同時に転写されることも明 らかとなった。 ORF 2 は 312 個のアミノ酸よりな るタンパク質 (BlaB) をコードし，この領域に BamHI リンカーを挿入すると約 $1 / 20$ に生産量が減 少することからアクチベーターをコードするものと 考えられた. しかし BESTFIT な゙ののプログラムで その相同性を検討すると $\mathrm{pBR} 322$ 由来の $\beta$-ラク夕 マーゼと 39.2\%の類似性を示し，さらにSXXKや $\mathrm{KS} / \mathrm{TG}$ などの $\beta$-ラクタマーゼの活性に必須なアミ ノ酸配列も検出された。しかしこのタンパク質は $\beta$

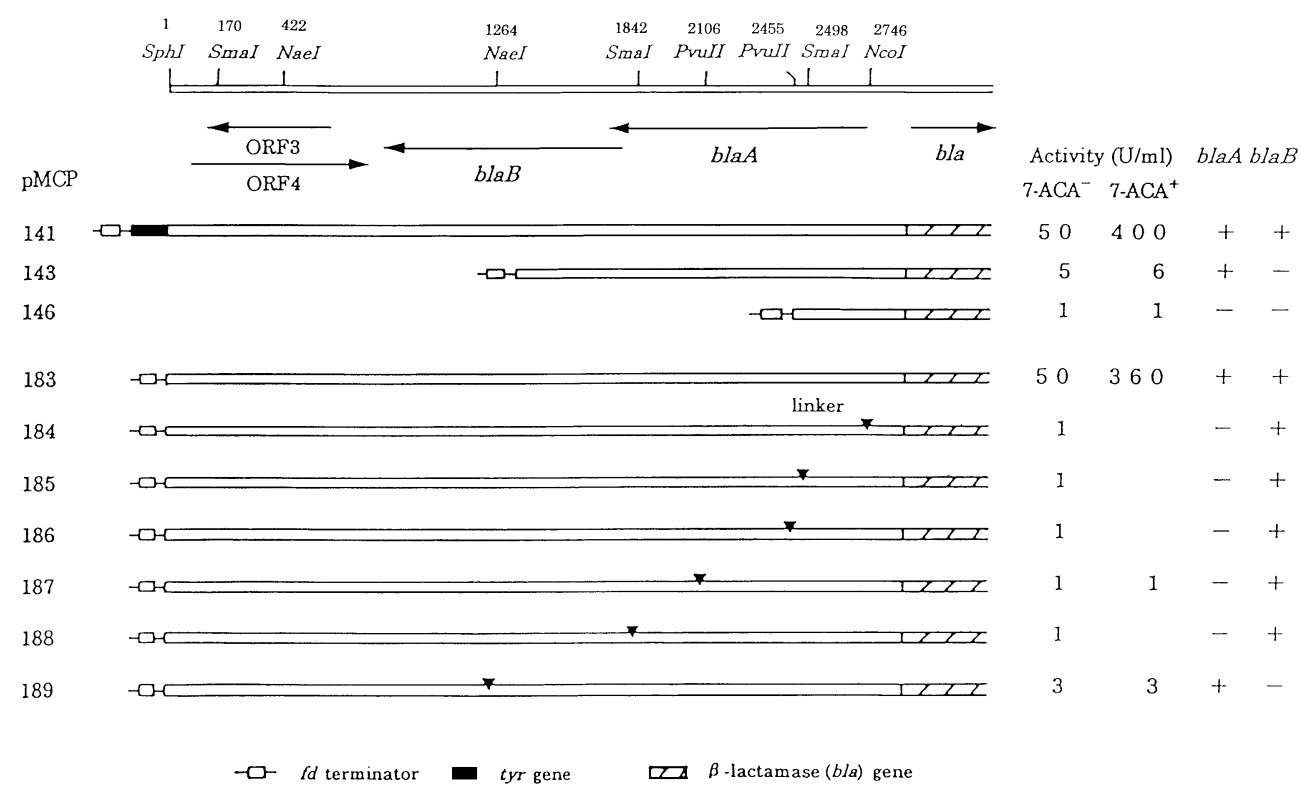

Fig. 2. Influence on bla Expression of Upstream Region of $S$. cacaoi DNA Fragments

$\beta$-Lactamase activity values (units per $\mathrm{ml}$ ) are those obtained with $S$. lividans 1326 harboring the indicated plasmids. The numbers above the restriction sites are those of the nucleotides from SphI site. Symbols: open bar: S. cacaoi, hatched bar: bla, closed car: thiostrepton resistance gene, closed triangle: BamHI linker, open box: $f b$ terminator. Arrows denote C-terminals of the indicated ORFs. 
ーラクタマーゼ活性を示さず， $\beta$-ラクタムを結合し てシグナルを BlaA に伝達するものと考えられる. ORF 3 及び ORF 4 は実際にタンパク質をコードし ているかどうか不明であり, 特に高い相同性を示す タンパク質も見あたらないが，両者は反対方向に重 複しておりこの領域に Bam HI リンカーを挿入する と発現する酵素量はやや増加することから酵素発現 に何らか負の作用をしていると考えられるが詳細は 不明である。以上の結果， BlaA 及び BlaBの 2 つ のタンパク質が $\beta$-ラクタマーゼの活性上昇に関係 することが明らかとなつたが，両遺伝子は酵素の誘 導にも必須であることも判明した。すなわち，通常 の状態でもS. lividans 中で BlaA 及び BlaB が存在 すると約 50 単位 $/ \mathrm{ml}$ の $\beta$-ラクタマーゼを生産する が，これに7-アミノセファロスポラン酸 (7-ACA) を添加すると 400 単位 $/ \mathrm{ml}$ まで上昇する。しかし BlaA あるいは BlaB のいずれかが欠失あるいは破 壊されているとこの誘導効果は全く見られない (Fig 2).すすおちこれら遺伝子は活性化のみでな く, 誘導現象にも梁く関わっていることが明らかと なつた. ${ }^{18)}$

それではこれら遺伝子がどのようにして $\beta$-ラク タマーゼの活性調節に関与しているのであろうか? 先程 BlaA タンパク質は DNA 結合モチーフを有す ると述べたが実際にBlaAが DNA に結合するかど うかをゲルシフトアッセイ，DN アーゼ I フットプ リントアッセイで調べた. ${ }^{19)}$ その結果, BlaA タン パク質は $\beta$-ラクタマーゼ構造遺伝子（bla, 29423919 位）と blaA との間の bla 転写開始点の直前で そのプロモーター領域を含む約 50 bp に結合するこ とが明らかとなった。この領域には繰り返し配列や 逆転繰り返し配列は存在しないが，G+C 含量が多 い放線菌であるにもかかわらず LysR 群タンパク質 の DNA 結合モチーフである $\mathrm{T}-\mathrm{A}$ に富む $\mathrm{T}-\mathrm{N}_{11}-\mathrm{A}$ 配列20)があることは特筆すべきことである．以上の 結果をまとめると, BlaB タンパク質が $\beta$-ラクタム 剂あるいはペプチドグリカン構成成分に対する一種 のセンサーとしてその情報を認識し, BlaA タンパ ク質にその情報を伝達し, BlaA タンパク質が BlaA と $\beta$-ラクタマーゼ構造遺伝子のプロモーター直前 の DNA 領域に結合することによりこれらタンパク 質の発現に正の効果をもたらしたものと考えられ る.アクチベーターハレプレッサーによる $\beta$-ラクタ
マーゼの発現調節は 2,3 のほかの菌でも知られて いるが，それぞれの菌でかなり異なった機構で調節 されていることは, ${ }^{21)}$ 個々の遺伝子がモザイク的に 寄り集まってこれら遺伝子発現調節系を形成した可 能性を示し, 遺伝子の進化の観点から大変興味深い.

つぎに S. cellulosae 由来でブルーデキストランを 結合する $\beta$-ラクタマーゼの遺伝子をショットガン 法で $2.3 \mathrm{~kb}$ の DNA 断片としてクローニングし た. ${ }^{22)}$ クローニングには SacI を用いたがこの過程 で片側の SacI 領域が欠失してしまった。しかしこ の遺伝子を有するクローンは親株に比較して約 6 倍 の $\beta$-ラクタマーゼ活性を示し，さらに硫酸アンモ ニウムで部分精製した酵素はブルーデキストランに 結合する性質を保持していた。ついでこの遺伝子の ヌクレオチド配列を決定した. ${ }^{23)}$ 前述したように, ある種のグラム陰性菌プラスミド由来の $\beta$-ラク夕 マーゼはクロキサシリンを加水分解し，ブルーデキ ストランを結合する（いわゆる D 型 $\beta$-ラクタマー ゼ). したがって S. cellulosae の $\beta$-ラクタマーゼも $\mathrm{D}$ 型 $\beta$-ラクタマーゼと相同性が高いものと予想さ れた. しかし，この予想に反して決定された配列は $\mathrm{D}$ 型 $\beta$-ラクタマーゼと全く相同性が見られず，逆 にグラム陽性菌から通常単離される $\mathrm{A}$ 型 $\beta$-ラク夕 マーゼと高い相同性を示した。ささら $\mathrm{NADP}^{+}$を 結合するタンパク質に特徵的な GXXGXXG とか RHXXXXR などと言つたアミノ酸配列も見い出せ なかった。したがって，この酵素による $\mathrm{NADP}^{+}$ の結合には特徵的なアミノ酸配列よりもむしろ全体 の立体構造が重要であると推定された。その点につ いては部位特異的変異導入による実験と関連してま た後で述べる.

それではほかのブルーデキストランを結合する放 線菌由来の $\beta$-ラクタマーゼではどうであろうか? この点を明らかにする目的で，ほかのブルーデキス トラン結合 $\beta$-ラクタマーゼの遺伝子をクローニン グし， ヌクレオチド配列を決定した。まず $S$. lavendulae $\mathrm{KCCS} 0263$ 由来 $\beta$-ラクタマーゼ遺伝子 を, S. cellulosae 由来 $\beta$-ラクタマーゼ遺伝子を用い る交雑法で $7.6 \mathrm{~kb}$ の DNA 断片としてクローニン グし， ヌクレオチド配列を決定した. ${ }^{24)}$ その結果は 先の S. cellulosae の場合と同様に A 型 $\beta$-ラクタ

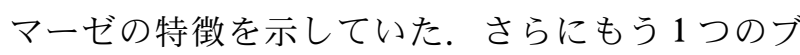
ルーデキストラン結合 $\beta$-ラクタマーゼの遺伝子を 
Streptomyces fradiae Y59 より同様の方法でクロー ニングし， $\beta$-ラクタマーゼ構造遺伝子領域のヌク レオチド配列を決定した. ${ }^{25)}$ その結果，S. fradiae Y59 の $\beta$-ラクタマーゼは 306 個のアミノ酸よりな り, S. cellulosae や S. lavendulae と同様 A 型 $\beta$-ラ クタマーゼの配列を有することが判明した. クロー ニングの過程で，これらの遺伝子では S. cacaoi の 場合と異なり上流領域が存在してもそれほど活性が 上昇しないことが示唆されていた．そこで $S$. cacaoi との比較を含めて S. fradiae Y59 の $\beta$-ラク タマーゼ構造遺伝子上流のヌクレオチド配列を決め ることとした。 その前に， $\beta$-ラクタマーゼ構造遺 伝子の上流約 $730 \mathrm{bp}$ の DNA 断片を持つプラスミ ド pMCP261 と上流約 $5 \mathrm{~kb}$ の DNA 断片を持つプ ラスミド pMCP229 を作成し，それぞれ別々に宿主 であるS. lividansへ形質転換し，その液体培養に 伴う酵素活性の時間経過と，7-アミノセファロスポ ラン酸による誘導現象を追跡した. ${ }^{26)}$ その結果, 上 流 $5 \mathrm{~kb}$ の領域が存在しても S. cacaoi の場合と異な り約 4 倍しか活性が上昇しないこと，7-アミノセフ アロスポラン酸が存在しても誘導現象は全く見られ ないことが判明した。このことは $\beta$-ラクタマーゼ 構造遺伝子の上流の遺伝子構成が, $S$. cacaoi と $S$. fradiae とで全く異なることを予想させた。 そこで この領域のヌクレオチド配列を決定してみると，予 想通り全く異なることが明らかとなった。一応 ORF らしき配列として4つ確認されたが，139個 のアミノ酸からなる ORF 4 がStreptomyces coelicolor A3 (2) 由来の調節タンパク質らしいタンパク 質（GenBank accession number AL031031-2）及び Actinosynnema pretiosum 由来のリファマイシン生 合成に関与する未知のタンパク質 (GenBank accession number U33059-2) とやや高い木モロジーを示 したのみで，ほかの ORF はいずれも少なくとも調 節タンパク質とは相同性は見られなかった。しかし 本当にこの ORF 4 が発現し, 調節に関与している かどうかは明らかにされていない.

次にどのアミノ酸がブルーデキストランとの結合 に関与しているかを S. fradiae Y59 の遺伝子を用 い, キメラ遺伝子を作成すると共に部位特異的変異 導入法を用いて検討した. ${ }^{25)} S$. cacaoi の遺伝子と比 較し S. cacaoi と S. fradiae の遺伝子をそれぞれ 3 分割しキメラプラスミドを作成し，S. lividans を形
質転換後 $\beta$-ラクタマーゼを部分精製し，ブルーデ キストランと混合し，Sephadexを通過させること により結合性を検討した。 S fradiae の $\beta$-ラクタ マーゼはブルーデキストランと混合して Sephadex カラムを通過させると複合体を形成するため先端に 溶出される，その結果，C 末端から約 1/3 の 194 位 から 306 位の領域はブルーデキストランの結合に関 与せず，むしろ結合に対して負の影響を示すことが 明らかとなった.さらに TSK AF-ブルーToyopearl $650 \mathrm{ML}$ ゲルを用いより定量的に解析した。 $\mathrm{N}$ 末端 より $2 / 3$ が S. fradiae 由来の場合, S. fradiae の場 合と同程度の結合性を示し, $\mathrm{N}$ 末端より $1 / 3$ が $S$. fradiae の場合は約 $1 / 2$ の酵素活性がカラムを通過 するが， $\mathrm{N}$ 末端 $1 / 3$ と C 末端 $1 / 3$ が $S$. fradiae の 場合は S. cacaoi の場合と同様結合性は消失する.

$\mathrm{N}$ 末端 $1 / 3$ が $S$. cacaoi の場合は S. cacaoi の場合と 同様全く結合しない。以上の結果は $\mathrm{N}$ 末端 $1 / 3$ が S. fradiae 酵素のブルーデキストラン結合性に必須 で, 中間の $1 / 3$ 部分はこの結合性を強化しているが, $C$ 末端 1/3 はこの結合性を弱めていることを示して いる. ついで前述の 3 種のブルーデキストラン結合 $\beta$-ラクタマーゼで共通のアミノ酸を $S$. c cacaoi の対 応するアミノ酸に置換する, 変位の領域をアミノ酸 40 位から 194 位に限定するの 2 点を考慮して部位 特異的置換を行った。その結果, G65R/T66D, R51K/T52K, R56H/L57P, D95Q, P79A/I80Y, R94L /D97L, E101R, H53V, S170Q/V171L, T86I/I87L の アミノ酸置換 $\beta$-ラクタマーゼ, $115 \mathrm{~K} / 116 \mathrm{R}$ の欠失 及び $125 \mathrm{~L} / 126 \mathrm{P}$ の欠失 $\beta$-ラクタマーゼでは結合に ほとんど影響を与えなかったが，E50Q アミノ酸置 換 $\beta$-ラクタマーゼでは S. fradiae の酵素よりやゃ 強く結合した. 以上の結果, S. fradiae 由来 $\beta$-ラク タマーゼのブルーデキストラン $/ \mathrm{NADP}^{+}$結合性 は，特定のアミノ酸と言うよりはむしろ結合部位全 体としての三次元構造によって決定されていると結 論した。同様の結論は大腸菌の D-グリセルアルデ ヒド-3-リン酸脱水素酵素でも知られている. ${ }^{27)} ま$ たこの変異導入で G65R/T66D や R51K/T52K では 酵素活性が上昇し， R56H/L57P と P79A/I80Y で は酵素活性がほとんど消失し，82SXFK85 の酵素活 性発現に必須なモチーフ近傍のアミノ酸置換が三次 元的立体構造を劇的に変化させ酵素活性発現に影響 を与えたものと推定された。 
3-4. $\beta$-ラクタマーゼの分類と進化 $\quad \beta$-ラクタ マーゼは病原菌が産生することで注目を集めている が, 同時に非病原性細菌である Streptomyces 属放 線菌やBacillus 更にはシアノバクテリア（藍藻，藍 色植物）も産生することが報告されている. ${ }^{28)}$ ただ し真核細胞であるカビは $\beta$-ラク夕ム抗生物質を産 生しているが， $\beta$-ラクタマーゼを生産するという 報告はない（ただ, Candidaなどある種のカビが $\beta$ ーラクタマーゼを産生するという古い報告はある が，これが現在言われている $\beta$-ラクタマーゼに相 当するかどうかは不明であり，むしろ産生しないと 考えた方が妥当である)。 $\beta$-ラクタマーゼはいくつ かの点でアミノグリコシドやマクロライド抗生物質 など，ほかの抗生物質の耐性に関与している酵素と は異なるように思える。例えば，化学修飾に限って 言えばアミノグリコシド抗生物質ではアセチル化,

リン酸化, AMP 化などいくつかの機構が耐性に関 与しているが, $\beta$-ラクタムの場合 $\beta$-ラクタマーゼ と言う一つの酵素で耐性をまかなつている．ただス トレプトマイシンでも生合成遺伝子のクラスター内 に存在しているのはリン酸化酵素のみのようであ る.またアミノグリコシド抗生物質では不活性化産 物であるリン酸化アミノグリコシドが生合成の中間 産物として生産されるが, $\beta$-ラクタムの場合は不 活性化産物であるぺニシロ酸は生合成中間産物では ないし, 細菌の $\beta$-ラクタム生合成遺伝子クラス ターには $\beta$-ラクタマーゼの遺伝子が存在するとは いえカビの $\beta$-ラクタム生合成遺伝子の中には $\beta$-ラ クタマーゼの遺伝子が存在しないことでも分かるよ うに, $\beta$-ラクタムの生合成に $\beta$-ラクタマーゼが関 与しているという証拠はない。一方， $\beta$-ラク夕 マーゼの生理的機能と関係して最近 Jacobs ら ${ }^{29)}$ は 大腸菌でのペプチドグリカンの合成と分解のバラン スを取るため, 細胞質で循環している前駆体のうち UDP-N-アセチルムラミルペンタペプチドとアン ヒドロ-N-アセチルムラミルトリペプチドとの相対 的な濃度比を感知することにより， $\beta$-ラクタマー ゼの発現が調節されているというモデルを提出し た. しかし大腸菌においても $\beta$-ラクタマーゼの生 理的機能は依然として不明であるし，グラム陽性菌 での機能は更に明確ではない。そこで病原菌 $\beta$-ラ クタマーゼとの進化上の関係を詳細に明らかにする 目的で, 従来の基質特異性, 物理化学的性質, 生化
学的性質に基づく分類とは異なり，最近明らかにさ れつつあるヌクレオチド配列/アミノ酸配列を基に 再分類することを試みた. ${ }^{30)}$ 近隣結合法で 系統樹を 作成すると, Fig. 3 に示すように従来の分類とわず か異なり $\beta$-ラクタマーゼは 6 群に分類された. 類 似の系統樹は他の方法例えば最尤法である Molphy などのプログラムでも得られたＩVI群は金属タンパ ク質で, 従来の分類では B 群に対応する。V群は OXA 型の $\beta$-ラクタマーゼであり，従来の分類では D 型に対応する. Fig. 3 に示した系統樹からも明ら かなように，これら 2 群の $\beta$-ラクタマーゼはほか の群の $\beta$-ラクタマーゼとは全く異なつた起源に由 来すると考えられる． III群は従来の分類の C 型に 対応し, I, II, VI 群の $\beta$-ラクタマーゼとは, Joris ら ${ }^{31)}$ が提唱する 7 個の $\beta$-ラクタマーゼモチー フ以外には共通のアミノ酸配列は見あたらない。ま た III群の $\beta$-ラクタマーゼには，A 型で I 群に属し 大腸菌由来の RTEM 型 $\beta$-ラクタマーゼの触媒活性 に関与していると考えられているアミノ酸配列 $\mathrm{SDN}$ も見い出せない. III群の $\beta$-ラクタマーゼで特 記すべき点は, グラム陰性菌で $\beta$-ラクタムを生産 しその生合成遺伝子のクラスターの一部となってい る Lysobacter lactamgenus の $\beta$-ラクタマーゼが, 大腸菌など $\beta$-ラクタムを生産しないグラム陰性菌 由来の $\beta$-ラクタマーゼとこの系統樹で近似の位置

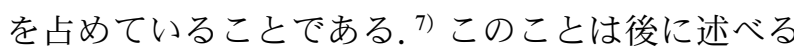
ように $\beta$-ラクタマーゼの起源を考える上で極めて 重要なことである.

私がここで提唱した分類の特徽は, 従来の分類の A 型 $\beta$-ラクタマーゼを I , II, VIの 3 群に細分化 したことである（I 群とII群は 1 つのグループと考 えてもよいかもしれない)，特に放線菌由来の $\beta$-ラ クタマーゼは，Bacillus cereus や Bacillus licheniformis などグラム陽性菌染色体に由来する $\beta$-ラク タマーゼに近似するグループと，Yersinia enterocolitica, Citrobacter diversus や Klebsiella oxyto$c a$ などグラム陰性菌染色体に由来する $\beta$-ラク夕 マーゼに近似するものに分類したことである.さら に前者には前述した Streptomyces cacaoi などの $\beta-$ ラクタマーゼが属し, 後者にはブルーデキストラン を結合する S. cellulosae, S. fradiae や S. lavendulae 由来の酵素が属することである. 実際に II群の放線 菌由来の $\beta$-ラクタマーゼと II 群のグラム陰性菌由 


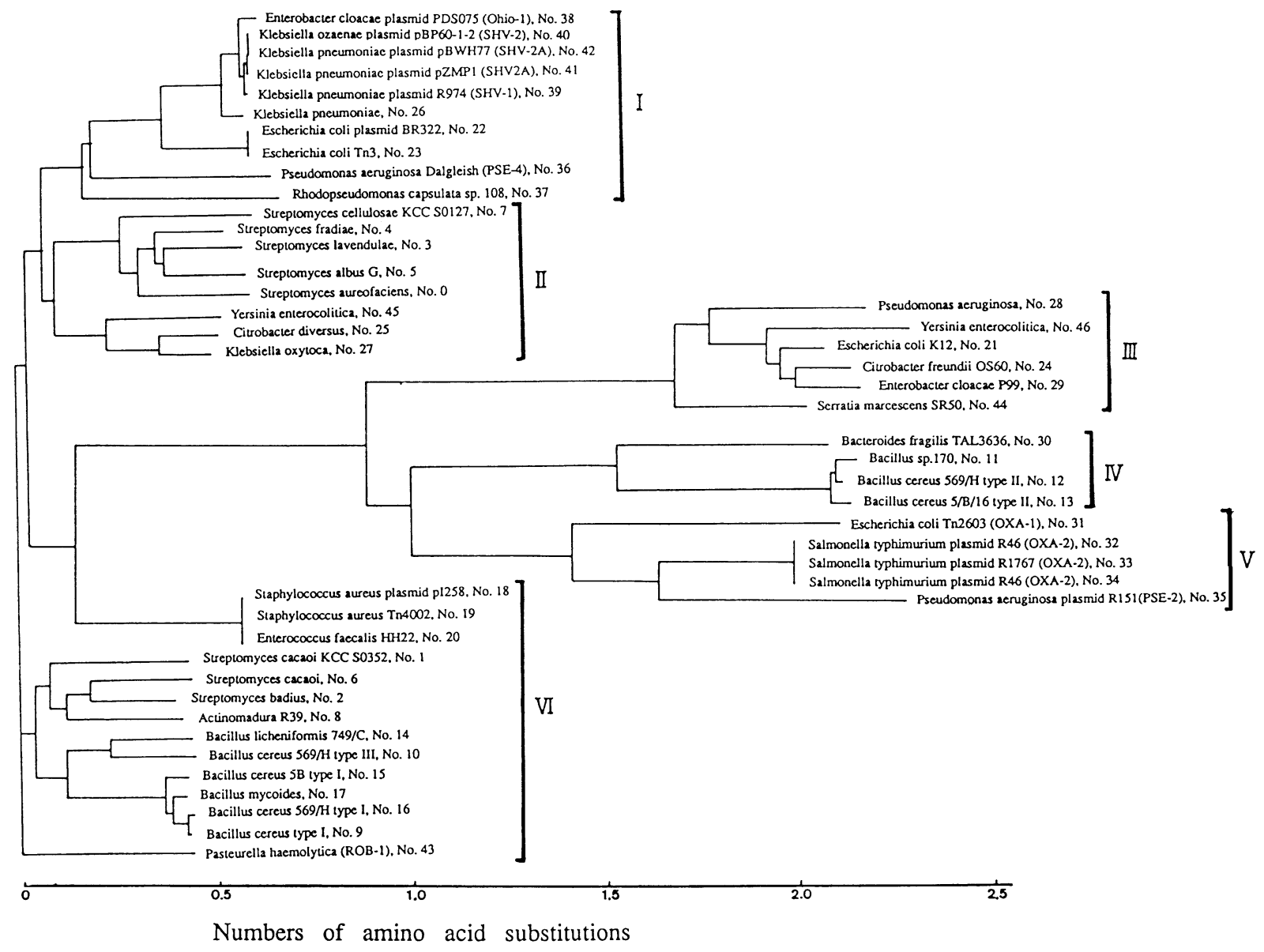

Fig. 3. Phylogenetic Tree Based on Amino Acid Sequence of $47 \beta$-Lactamases The tree was constructed by the neighbor-joining method. ${ }^{53)}$

来 $\beta$-ラクタマーゼの間のアミノ酸置換数は，II 群 の放線菌由来の $\beta$-ラクタマーゼとVI群の放線菌由 来 $\beta$-ラクタマーゼ間のアミノ酸置換数より少な <，放線菌同士より II 群内の $\beta$-ラクタマーゼ同士 の方がアミノ酸配列として近似していることが確認 された.このことは $\beta$-ラクタマーゼの進化を考え る上で大変重要なことである．また後述するように 現在はStreptomycesにおいて $\beta$ にラクタマーゼは耐 性にそれほど大きく寄与していないと思われるが， 少なくともかつては $\beta$-ラク夕ム耐性の主要な原因 を担っていたものと考えられる。このようなことを 考えつつFig. 3 に示した系統樹から想像をたくま しくして $\beta$-ラクタマーゼの進化の様子を推定すれ ば，次のようになるであろう。すなわち，放線菌の II 群の $\beta$-ラクタマーゼ遺伝子は Y. enterocolitica などグラム陰性菌に伝達されると共にグラム陰性菌 のプラスミドに伝達され, 現在のグラム陰性病原細 菌における $\beta$-ラクタム耐性の主要な原因となり,
もう一方のVI群の放線菌 $\beta$-ラクタマーゼ遺伝子は B. cereus などと共にグラム陽性菌のプラスミドに 伝達されグラム陽性菌での $\beta$-ラクタム耐性の主要 な原因となったとするものである. 両者ともぺニシ リンの分解を主とするペニシリナーゼ型である特徵 を有する. 一方, L. lactamgenus のようなグラム陰 性菌で $\beta$-ラクタムを生産する細菌に由来する $\beta$-ラ クタマーゼは, 大腸菌などグラム陰性菌に伝達され セファロスポリンを主として加水分解する一群の $\beta$ ーラクタマーゼ（いわゆるセファロスポリナーゼ） を形成したと考えられる，すなわち，現在存在する $\beta$-ラクタマーゼは $\beta$-ラクタム抗生物質を生産する 2 つのグループすなわち放線菌で代表されるグラム 陽性菌とLysobacter で代表されるグラム陰性菌に 由来し，それぞれが基質特異性の異なる一群の酵素 を形成したというものである. もう一点, ROB-1 $\beta$ -ラクタマーゼ（No. 43）の基質特異性やクラブラ ン酸による阻害は I 群のグラム陰性菌プラスミド由 
来の $\beta$-ラクタマーゼと類似するが, Pasteurella や Haemophilus などのプラスミドによっても仲介さ れている.しかしまた Pasteurella aerogenes の 1 菌 株ではその染色体によってもコードされている.こ れらの結果, ROB- $1 \beta-$ ラタターゼはグラム陽性 菌の $\beta$-ラクタマーゼとグラム陰性菌の $\beta$-ラクタ マーゼを繋ぐリンクをなしているのではないかと想 像される.このことはいくつかのアミノ酸配列の保 存性からも支持される， $\beta$-ラクタマーゼの進化を 考えた場合，グラム陽性菌例えば，B. cereus, Streptomyces lavendulae, Streptomyces cacaoi など はアミノ酸配列の類似した複数の $\beta$-ラクタマーゼ を生産していることも興味深い，以上を読むと遺伝 子は勝手に動き回っているように思われるであろう が，実際そうであるという例を私どもの研究から 1 つ挙げてみよう.

大腸菌の $\beta$-ラクタマーゼ遺伝子をプローブにし て, GenBank データベースで TFASTA プログラム を用いアミノ酸配列の類似性をスクリーニングして みると, 硝酸還元性のグラム陰性菌である Paracoccus denitrificans のチトクロームオキシダー ゼサブユニット II の翻訳領域上流約 $50 \mathrm{bp}$ のヌクレ オチド配列から帰納したアミノ酸配列は，グラム陰 性菌染色体由来 $\beta$-ラクタマーゼの約 130 個のアミ ノ酸配列と異常に高い相同性を示すことが判明し た. ${ }^{32)}$ 京大の宮田隆教授らとの共同研究で，このよ うな事象が偶然に起こる確率は $10^{-17}$ 以下であるこ とが明らかになった. しかしこの配列は約 110 個の アミノ酸領域に限られ，その前後では全く相同性は 見られなかった。 また $\beta$-ラクタマーゼの活性発現 に必須なアミノ酸配列のうち一部を保持していたが, SXXKなどのモチーフは欠いていた。さらにヌク レオチド配列で比較しても $\beta$-ラクタマーゼの一部 の領域のみが相同性が高くその前後では全く相同性 は見られなかった。 すなわち，P. denitrificansで見 い出された配列はグラム陰性菌 $\beta$-ラクタマーゼの 配列の一部であることが明らかとなった。しかもこ の配列はコドン利用性，5S rRNA に基づく菌の系 統関係などの解析からP. denitrificans それ自身に 由来するものであり，大腸菌など他の菌由来でない ことも判明した. 現在 $P$. denitrificans が $\beta$-ラクタ マーゼを生産するかどうか不明であるが， $\beta$-ラク タマーゼ遺伝子の断片が転座して出現したと言うこ
とは DNA 断片が想像以上に転座しやすいことを示 している. しかもこの場合, ヌクレオチド断片の両 端には逆転繰り返し配列や繰り返し配列と言つた転 座の際よく見られる配列は存在しないので, 現在未 知の機構でも転座は容易に起こるものと考えられる.

\section{4. 放線菌のペニシリン結合タンパク質}

前述したように多くの放線菌は， $\beta$-ラク夕ム耐 性とは無関係に菌体外に $\beta$-ラクタマーゼを分泌す る.このことは少なくとも現在において， $\beta$-ラク タマーゼは自己耐性にほとんど関与していないこと を意味している。それでは何が放線菌での $\beta$-ラク 夕ム耐性に関与しているのであろうか? そこで $\beta-$ ラクタムを生産しない Streptomyces cacaoi と $\beta$-ラ ク夕ムを生産するStreptomyces olivaceus 及び Streptomyces clavuligerus の 3 種の放線菌のペニシ リン結合タンパク質（PBP）をその当時定法にな っていたフルオログラフィーを用いて検討した. その結果判明したことは, 放線菌の PBP は一般に 他の細菌で見られない特徵を示すと言うことであ る. 第一に放線菌の PBP はいずれも $\beta$-ラクタムの 生産とは無関係にベンジルペニシリンに対する親和 性が極めて低い. ${ }^{33)}$ 最も高いS. cacaoi のPBP 3 （M64）でも飽和するには $10 \mu \mathrm{g} / \mathrm{ml}$ のベンジルペニ シリンを必要とし, 大腸菌などの数 10 倍も検出に 時間が必要である。これは放線菌がグラム陽性菌で あるにもかかわらず非常に高い MIC 值を示すこと に反映している，例えば，大腸菌では $\left[{ }^{14} \mathrm{C}\right]$ ベン ジルペニシリンを用いた場合， $1-2$ 日の感光で PBP が検出できるが, 放線菌の場合, 同様の条件 下で 2 - 6 力月必要である. 第二に $\beta$-ラク夕ムを生 産せず $\beta$-ラクタマーゼを生産する $S$. cacaoi の場 合, 膜結合 PBPとして分子量 105000 (以下 M105), M91, M64, M55, M47 の少なくとも 5 種類 の, 条件によっては 9 種以上のタンパク質が検出で きた。一方，S. olivaceus とS. clavuligerus の場合 はそれぞれ 2 個及び 5 個のタンパク質しか検出でき なかった。この原因として菌の生育時期による影響 とか菌による可溶化の条件が異なる，いくつかの PBP は生存に必須ではないなどの可能性が考えら れるが, PBP が細胞壁の伸長, 隔壁の形成などに 関与しているとすると 2 個と言うのはいかにも少な すぎる，そこで一番考え得る可能性は $\beta$-ラク夕ム の生産がPBP の見かけ上の数に影響を与えている 
というものである. $\beta$-ラクタムを生産する $S$. olivaceus や S. clavuligerus の方が， $\beta$-ラクタムを 生産せず, $\beta$-ラクタマーゼを生産する $S$. cacaoi りベンジルペニシリンに対して耐性度が高く, 前者 のPBP のフルオログラフィーバンドが後者のもの より薄いと言うことは上記のことを支持している. 第三に S. cacaoi においてはメシリナムは M91 に結 合するし，メチシリンはM105, M64 及びM55 に 結合し，クラブラン酸は高濃度でのみ PBP 1 (M105) に結合するが，S. olivaceus, S. clavuligerus においては濃度が高くてもいずれの PBPにも結合 しない．第四に $\beta$-ラクタム非生産菌の PBP は互い に類似しこれはほかの細菌のものとも類似するが, $\beta$-ラクタム生産菌の PBP は互いにも全く異なる. 第五に放線菌の生育時期も特に $\beta$-ラク夕ム生産菌 のPBP パターンに大きな影響を与えている。ささ に培養上清, 細胞質内の PBP についてもこれら $\beta-$ ラクタム生産菌と非生産菌ではその PBP の数が異 なる．この $\beta$-ラクタム生産による PBP パターンの 差異はこれらがいずれも同じ属に属することを考え ると顕著な特徽である。例えば， E. coli, S. typhimurium, P. aeruginosa は異なる属であるが類 似の PBP パターンを与え，B. subtilis，B. licheniformis, B. megaterium はまたほぼ同一のパターンを 与えるからである。また PBP・ベンジルペニシリ ン複合体からの $\left[{ }^{14} \mathrm{C}\right]$ の遊離が一般に極めて遅い ことも特徵である．その上，いずれの PBPでも完 全な遊離は見られない.さらに放線菌の $\beta$-ラクタ ム耐性における PBP の役割を追跡するために NTG 処理によりペニシリン高度耐性株を取得した（親株 のベンジルペニシリンに対する $\mathrm{MIC}=100-250 \mu \mathrm{g}$ $/ \mathrm{ml}$, 変異株の $\mathrm{MIC}=1,000-4,000 \mu \mathrm{g} / \mathrm{ml})$ 結果, この変異株では同時にメシリナム, セファマイシン C，メチシリンに対する MIC 值も上昇していた. この変異株の PBP パターンで 2 つ特異な変化が 見られた。第一にPBP 1*（M130）の量が異常に増 加したことである. 第二にベンジルペニシリンなど の PBP 特に多くの $\beta$-ラク夕ムの標的と考えられる PBP 2 (M91) に対する親和性が低下したことであ る. ${ }^{34)}$ 以上の結果は, 放線菌の $\beta$-ラクタムに対す る耐性の主要な原因は PBP の本質的な構造変化で あることを更に裏付けるものである. ${ }^{35)}$

私たちは放線菌由来主要 PBP の遺伝子をクロー
ニングし，さらに放線菌の $\beta$-ラクタム耐性におけ るPBP の役割を詳細に検討すべく色々努力したが， PBP を短時間で検出する方法がネックになって成 功しなかった。 最近 Kendrick ら ${ }^{36)}$ は胞子形成と関 連して，フルオレッセインを結合したペニシリンを 用いPBP を迅速に検出する方法を開発した。 しか し誠に残念なことに，詳細な方法を聞く前に彼女は 亡くなってしまった.

\section{5. 放線菌の真核生物型タンパク質キナーゼ}

5-1. 遺伝子のクローニング 真核生物, 原核 生物を問わずリン酸化はシグナル伝達系の主要な調 節機構の 1 つである. しかし興味あることに最近ま で原核生物の主要なリン酸化部位はヒスチジン/ア スパラギン酸 ${ }^{37)}$ であり，真核生物ではチロシンあ るいはセリン/スレオニン38)であると考えられてき た。一方で，ヒスチジン/アスパラギン酸系（いわ ゆる二成分系）のリン酸化は 10 年ほど前，植物な ぞで検出され, ${ }^{39)}$ また非真核生物型チロシンあるい はセリン/スレオニンリン酸化系は古くから原核生 物でも知られていた。 1991 年になり Munoz-Dorado ら ${ }^{40)}$ は真核生物由来タンパク質キナーゼの保存 領域のヌクレオチド配列に基づいた PCR 法を用 い, グラム陰性菌で特徽的な形態分化を示す Myxococcus xanthus より真核生物型セリン/スレオニン キナーゼ遺伝子をクローニングした。放線菌は種々 の二次代謝産物を産生 (生理学的/生化学的分化) すると共に, 気中菌糸/胞子形成 (形態学的分化) を行うことが知られている。そこで放線菌の複雑な 分化過程に真核生物型タンパク質キナーゼが関与す るのではないかと考え, Myxococcus と類似の方法 でその遺伝子を Streptomyces coelicolor A3 (2)より クローニングすることを試みた。 その結果，現在ま でのところ 7 種類の真核生物型タンパク質キナーゼ 遺伝子がクローニングできた。現在, 英国の Hopwood 教授を中心にS. coelicolor DNA の全塩基配 列が決定されつつあるが，それによれば 20 種以上 の真核生物型タンパク質キナーゼ様遺伝子の存在が 確認されている. 最初に 7 種のうち 2 種のタンパク

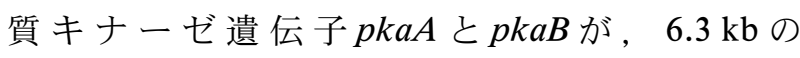
Bam HI 断片としてクローニングされた. ${ }^{41)}$ そのヌ クレオチド配列を決定してみると, $p k a A$ と $p k a B$ が縦列に並びそのほかタンパク質合成の遊離因子遺 伝子（prfB）がこれも同じ方向に存在した 


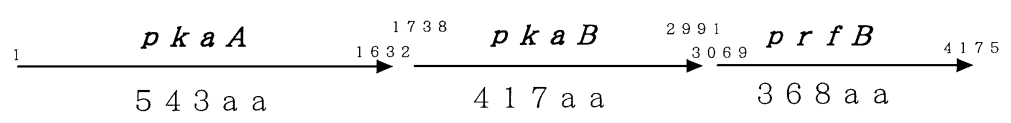

Fig. 4. The Relative Positions of the Genes, $p k a A, p k a B$ and $p r f B$

The numbers of amino acid residues are indicated below the gene and the numbers of nucleotides from 5'-end of $p k a A$ are shown beside the gene. The arrows denote C-terminals of the indicated ORFs.

(Fig. 4). ${ }^{42)} \mathrm{PkaA}$ は 543 個のアミノ酸よりなり, PkaB は 417 個のアミノ酸よりなる. 両タンパク質 共に $\mathrm{N}$ 末端領域は真核生物型キナーゼの触媒ドメ イン共通配列 I 〜 XI をすべて含み，一方 C 末端側 は互いに共通配列を持たずそれぞれ特有の配列を持 つていた。ついでこれら遺伝子が本当にタンパク質 キナーゼ活性を発現しているかどうか，大腸菌発現 系を用い検討した。その結果, pkaA は pET3a 系 では発現せず，グルタチオン S-トランスフェラー ゼとの融合タンパク質として発現できた. IPTGで 誘導すると融合タンパク質の分子量に相当する 84 $\mathrm{kDa}$ のバンドのみが誘導され，さらに $\left[{ }^{32} \mathrm{P}\right]$ ある いは $\left[{ }^{35} \mathrm{~S}\right]$ メチオニン+ $\left[{ }^{35} \mathrm{~S}\right]$ システインを用い て検討した結果， $84 \mathrm{kDa}$ のバンドのみが特異的に 誘導発現した。また $\left.{ }^{[32} \mathrm{P}\right]$ で標識したバンドを抽 出し $6 \mathrm{M} \mathrm{HCl}$ で加水分解してどのアミノ酸がリン 酸化されるかを調べるとスレオニンが強く, セリン が弱くリン酸化されていた．以上の結果，pkaA 遺 伝子は大腸菌で発現し自己リン酸化し，真核生物の キナーゼと異なり主としてスレオニンをリン酸化す るキナーゼであることが判明した。 また，pkaA 遺 伝子の $\mathrm{C}$ 末端部分を削り 439 個のアミノ酸からな るタンパク質でも同様にキナーゼ活性を示した。す なわち, pkaAの $\mathrm{C}$ 末端側約 100 アミノ酸は，キ ナーゼ活性には関与していないことも明らかになつ た.一方, $p k a B$ は $\mathrm{pET} 3 \mathrm{a}$ 系で発現され, $p k a A$ と 同様に解析した結果, $p k a B$ もキナーゼ活性を示し リン酸化されるアミノ酸はスレオニンで, セリン, チロシンはリン酸化されなかった。先程 $\mathrm{C}$ 末端側 のアミノ酸配列はそれぞれ特有の配列を示すと述べ たが, PkaA タンパク質のC 末端はプロリンとグル タミン酸に富み, 真核細胞の転写因子である $\mathrm{Sp} 1$ がプロリンとグルタミン酸に富むことから考えて,

PkaA は DNA 結合タンパク質である可能性が示唆 される.なお, $p k a A, p k a B$ と $p r f B$ の 3 種の遺伝 子が縦列に存在するが, これら遺伝子はいずれも monocistronicに発現していた。 また $p k a B$ 遺伝子
の保存領域を用い他の放線菌と交雑させると調べた すべての放線菌で交雑するバンドが見られることか ら，ここに述べた真核生物型タンパク質キナーゼ は，放線菌に幅広く分布し，何らかの生理的役割を 果たしているものと思われる。ここで prfBについ て少々述べたい。原核生物の遊離因子には RF1 と $\mathrm{RF} 2$ の 2 つが存在し, 後者はUGA とUAA コドン での終止を触媒する。現在までにE. coli, $S$. typhimurium, B. subtilis のグラム陰性菌, グラム陽 性菌の両者から RF2 の遺伝子がクローニングされ ているが，いずれも途中に未熟な UGA 終止コドン を含み, この位置で終止することなしに+1の frameshift を起こし, RF1 特異的終止コドンである UAG まで読み進み，ここで終止し， RF2の合成を 完成する.さらに+1の frameshift を起こすのに必 要な Shine-Dalgarno 様配列43) と homopolymeric 配 列44)が存在するが，放線菌ではこのような途中の終 止コドンはないし， +1 frameshift や Shine-Dalgarno 様配列も存在しない。さらに放線菌の RF2 の終止コドンはRF1 も RF2 も触媒するUAA コド ンである. ${ }^{42)}$ 同じグラム陽性菌であるB. subtilis で も大腸菌と同様なことが見られるので, 放線菌でど うしてこのような現象が見られるか不思議である.

ついで $p k a B$ のキナーゼドメインVI，VII，VIIIを含 む $165 \mathrm{bp}$ の PCR 反応生成物をプローブにして $S$. coelicolor 染色体 DNA と交雑することにより, sch1, sch2-1, sch2-2, sch3, sch4, sch5, sch6 の 7 種の $1.8 \mathrm{~kb}$ から $9.4 \mathrm{~kb}$ の DNA 断片をクローニングし た。ついでこれら断片をプローブにコード領域の DNA 断片をクローニングし， ヌクレオチド配列を 決定した。その結果, sch1 は5 510 個のアミノ酸か らなるPkaEを，sch3 は667個のアミノ酸からな る $\mathrm{PkaF}$ を, sch4は592個のアミノ酸からなる $\mathrm{PkaG}$ を, sch5 は 598 個のアミノ酸からなる $\mathrm{PkaD}$ を, sch6は745個のアミノ酸からなる $\mathrm{PkaC}$ を コードしていることが明らかになった。 また Sch21 は堀之内らが既にクローニングしている AfsK で 
あり, ${ }^{45)} \mathrm{Sch} 2-2$ は ABCトランスポーターであっ

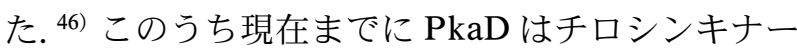
ゼ活性を示し，その他弱いスレオニンキナーゼ活性 を示すがセリンはリン酸化しないこと，PkaE はス レオニンキナーゼ活性と弱いセリンキナーゼ活性を 示すことが判明している.これら 7 種のタンパク質 のヌクレオチド配列から帰納したアミノ酸配列を Fig. 5 に示す.このアミノ酸配列の比較からも明ら かなように， $\mathrm{N}$ 末端はキナーゼドメイン特にドメ インVI，VII及びVIII゙よく保存されているのに反して， $\mathrm{C}$ 末端側にはほとんど共通配列が見あたらない。先 程も述べたように，この領域はそれぞれのキナーゼ に特有の機能を果たすために必要な領域と思われ る. また Fig. 6 に示すように，これらのキナーゼ 様遺伝子は PkaA と $\mathrm{PkaB}$ が, PkaD, PkaH, PkaI と PkaJ がクラスターをなしている以外染色体地図 上でばらばらの位置に存在していることも，その機 能を考えた場合興味深いものがある.

ここでクローニングした真核生物型タンパク質キ
ナーゼのいくつかは，実際にキナーゼ活性を持って いることが大腸菌を用いた発現系で明らかになった が，それではこれらキナーゼは放線菌内でどのよう な機能を持っているのであろうか?そこで $p k a A$ 遺 伝子と $p k a B$ 遺伝子を別々に破壊しどのような形質 の変化が起こってくるかを調べた. ${ }^{47)} こ の$ 結果,

$p k a A$ 遺伝子を破壊すると, グルコースを含む最小 培地で気中菌糸を作らなくなり, 抗生物質の一種で あるウンデシルプロジギオシンの生産が低下する が，もう一方の抗生物質であるアクチノロジンの生 産には影響しないことが判明した。他方 $p k a B$ 遺伝 子を破壊すると, グルコースを含む最小培地で気中 菌糸を作らなくなる点は共通するが, 抗生物質アク チノロジンの生産は減少し，もう一方のウンデシル プロジギオシンの生産には影響を与えないという, 抗生物質生産に対しては $p k a A$ と逆の結果となつ た。いずれにしても，PkaA と PkaB の両者ともに 気中菌系の形成という形態学的分化と抗生物質の生 産という生理学的あるいは生化学的分化に影響を与

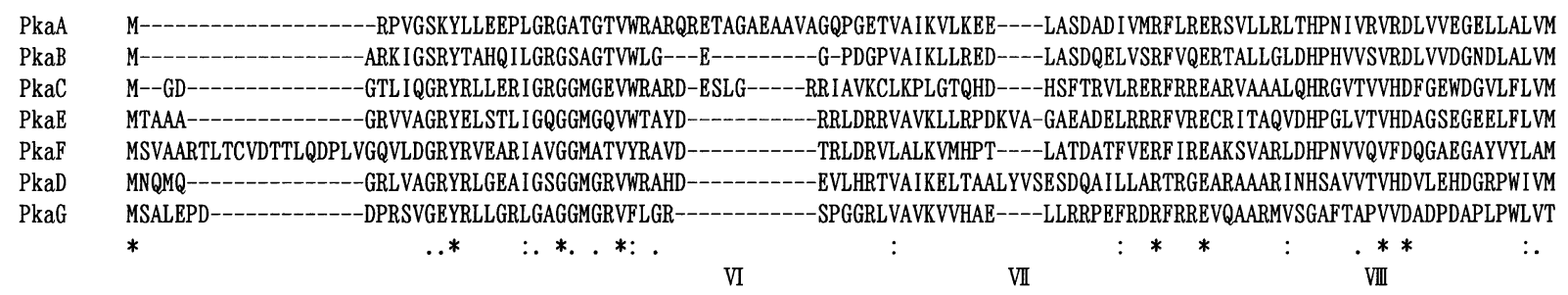

PkaA N-GATSVLPHTSG--PAGAADPTAVLPSTGAPDPTA-----VMPPVPPGQ-

PkaB V-RRRGAVPLVPGAKPADSNRDTHTSMRVPAPDELAGGARGTARAPRASGAP

PkaC H-KATGPGPATP--PDPGAGLSGEWIPRPTGDGTDGGR---TVGPVP----

PkaE --AAEAAKPDVAR-AVDDVKRLLGEGRITQAVDVLG-----AILPAAAEQ-

PkaF R-ALTMPRPLPVN-EDDGSAGPDGRFASDGGFGADG-------VNRTSRLA-

PkaD QAGGSGATPYPPT-TGPTGAGPAPTGHTRGGYTQVGHTEGG-YTAPGYAP--

PkaG PAQVYPPAPAPADVRPTATGDGGRRSRRAFLF SGAG------ALAALGVGT-

Fig. 5. Comparison of Amino Acid Sequences of the Conserved Region of Seven Eukaryotic-Type Protein Kinases from S. coelicolor A3 (2)

The three kinase domains VI, VII and VIII are indicated. The identical amino acids among these kinases are marked with asterisk. 


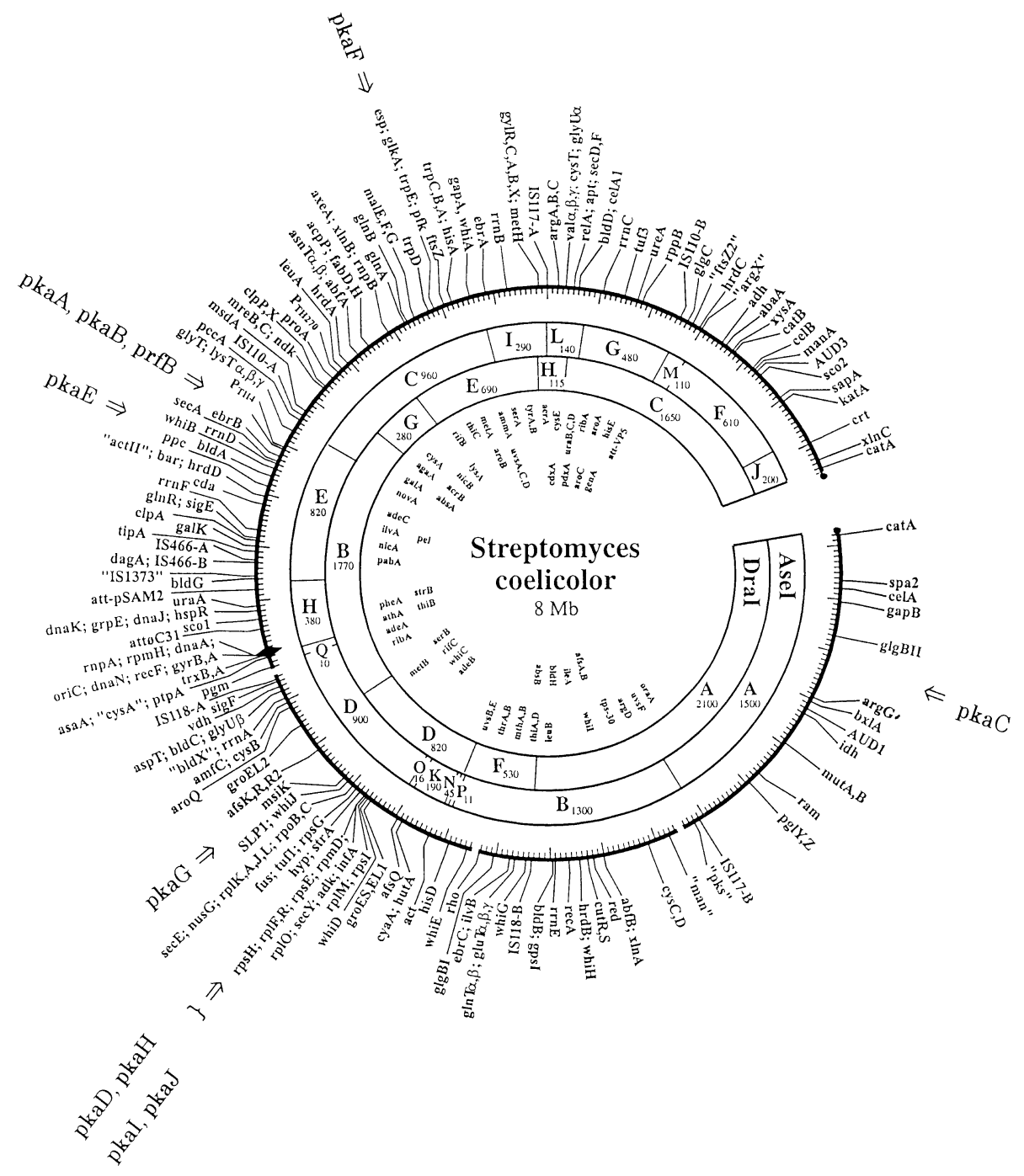

Fig. 6. Approximate Positions of Eukaryotic-Type Protein Kinase-Like Genes on the Chromosome of S. coelicolor A3 (2) The map was constructed by a slight modification of Fig. 20.1 of the reference. ${ }^{59}$

えていることが明らかとなった。しかし 20 種以上の 真核生物型タンパク質キナーゼがどのような順序で シグナルを伝達し，放線菌における分化過程にごの ように影響を与えているかは今後に残された問題で ある。

5-2. 分類と進化 ここ数年 20 種近くの微生 物の全塩基配列が決定され, 新たに続々と全塩基配 列が決定されつつあると同時に, ヒトのゲノムの塩 基配列も今年中にはほとんど解明されようとしてい る.このような状況になってみると, これまで述べ てきたいわゆる真核生物型タンパク質キナーゼがど の範囲の原核生物に分布し，そのキナーゼ同士でど のような進化上の関係があるか興味が持たれる，そ こで各種細菌でどのように真核生物型タンパク質キ ナーゼが分布しているかを 2 成分系の分布と対比し
て調べてみた. ${ }^{48)}$ その結果を Table 5 に示す。この 表から明らかなように, 真核生物型キナーゼは原核 生物で偏在していることが際だつた特徵である. 例 えば, proteobacteriaで言えば，E. coliやH. influenzae では検出できないのに対して, 特異な分化 をする M. xanthusでは 6 種以上存在している. ま たグラム陽性菌では胞子を形成する B. subtilis でも 2 種しか検出されていないにもかかわらず，M. tuberculosis や S. coelicolor では 10 種以上見い出さ れている.さらに, 真核生物に近いとされる archaea bacteria では P. horikoshii で 1 種検出されて いるが他の種では全く検出されていない.これに反 して, 従来原核生物で知られてきた 2 成分系のヒス チジン/アスパラギン酸キナーゼ系は P. horikoshii で 1 種しか検出されないと言う例外を除いて，いず 
Table 5. Distribution of Protein Kinases in Bacteria

\begin{tabular}{|c|c|c|c|c|}
\hline Category & Species & $\underset{(\mathrm{bp})}{\text { Genome size }}$ & $\begin{array}{l}\text { Number of eukaryotic- } \\
\text { type protein kinase }\end{array}$ & $\begin{array}{l}\text { Number of two } \\
\text { component system }\end{array}$ \\
\hline \multirow[t]{4}{*}{ Proteobacteria } & E. coli & $4,639,221$ & 0 & 30 \\
\hline & H. influenzae & $1,830,135$ & 0 & 4 \\
\hline & H. pylori & $1,667,867$ & 1 & 4 \\
\hline & M. xanthus & - & $>6$ & - \\
\hline \multirow{5}{*}{$\begin{array}{l}\text { Gram-positive } \\
\text { bacteria }\end{array}$} & B. subtilis & $4,214,814$ & 2 & 36 \\
\hline & M. genitalium & 580,073 & 1 & - \\
\hline & M. pneumoniae & 816,394 & 1 & - \\
\hline & M. tuberculosis & $4,411,529$ & 11 & 14 \\
\hline & S. coelicolor & - & $>20$ & - \\
\hline Chlamydia & C. trachomatis & $1,042,519$ & 2 & - \\
\hline \multirow[t]{2}{*}{ Spirochete } & B. burgdorferi & 910,724 & 0 & 4 \\
\hline & T. pallidum & $1,138,011$ & 0 & 3 \\
\hline Rickettsia & R. prowazekii & $1,111,523$ & 0 & 4 \\
\hline $\mathrm{O}_{2}-$ reducing bacteria & A. aeolicus & $1,551,335$ & 1 & 4 \\
\hline Cyanobacteria & Synechocystis sp. & $3,573,470$ & 8 & 32 \\
\hline \multirow[t]{4}{*}{ Archaea } & M. jannaschii & $1,664,987$ & 0 & - \\
\hline & M. thermoautotrophicum & $1,751,377$ & 0 & 15 \\
\hline & A. fulgidus & $2,178,400$ & 0 & 24 \\
\hline & P. horikoshii & $1,738,505$ & 1 & 1 \\
\hline
\end{tabular}

れも数種検出されている. ${ }^{49)}$ これはどうしてなので あろうか? 5 種以上検出されている種を見るといず れも極めて特徵的な分化を示すと言う特性を持って いることが分かる．例えば，M. xanthusは胞子の 詰まった果実体を形成し，滑るように固体表面を移 動する.M. tuberculosis と M. leprae（5 種以上の 真核生物型タンパク質キナーゼを有している）はい ずれも極めてゆっくりとしか生育しないし，ある条 件下では未発達な菌体を形成する。また S. coelicolor は気中菌糸や胞子を形成すると共に抗生物 質などの二次代謝産物を生産する。さらにSynechocystis sp. は藍藻で, 真核生物の葉緑体の起源 と考えられているチラコイドを形成する。したがつ て, 真核生物型タンパク質キナーゼは進化の過程 で，これら特殊な種のみで保存されてきたと考えら れる. そこで次に保存領域のアミノ酸配列に基づく 系統樹を近隣結合法（Clustal W) で作成し，その 類似性を比較，検討した（Fig. 7)。その結果, Zhang ${ }^{50)}$ が言うようにある種からのキナーゼは 1 つ のクラスターの一部になるが，必ずしもそうではな いことが判明した。例えば，C. trachomatis からの CTPknD とCTPkn5 は異なる枝に属し，M. tuberculosis のキナーゼ遺伝子は色々な枝に分散してい
る. しかも分岐後置換頻度がいずれもかなり高い. と言うことは，それぞれのキナーゼは分岐後高い頻 度でアミノ酸を置換したことを示している。この点 はRdf2 プログラム ${ }^{51)}$ 及び PROTDIST プログラ ム ${ }^{52)}$ で解析することにより確認された。すなわち, キナーゼ反応に必要な主要なアミノ酸は保存されて いるが，1菌種からのキナーゼであっても原核生物 の真核生物型タンパク質キナーゼはある場合には互 いに遠い距離でしか関係していないことが判明し た.さらに真核生物由来の遺伝子も原核生物由来の 遺伝子と系統樹上区別できないほど類似しているこ とも明らかとなった。同様な系統樹はほかの方法す なわち Oden (近隣結合法), ${ }^{53)}$ Molphy（最尤法), ${ }^{54)}$ Phylip (最大節約法) ${ }^{52)}$ でも得られ，上記のことが 確認された.

次にこれらキナーゼ遺伝子の $\mathrm{G}+\mathrm{C}$ 含量を由来種 の遺伝子の平均 $\mathrm{G}+\mathrm{C}$ 含量と比較すると, 2,3 の例 外を除いていずれも由来種の遺伝子の $\mathrm{G}+\mathrm{C}$ 含量に 近いことが判明した（Table 6)。このことは，キ ナーゼ遺伝子のコドン利用性が保持されており，ほ かの遺伝子に近いことを示している。これらの結 果，真核生物型のタンパク質キナーゼは，真核生物 が原核生物から分離する以前から原核生物に存在 


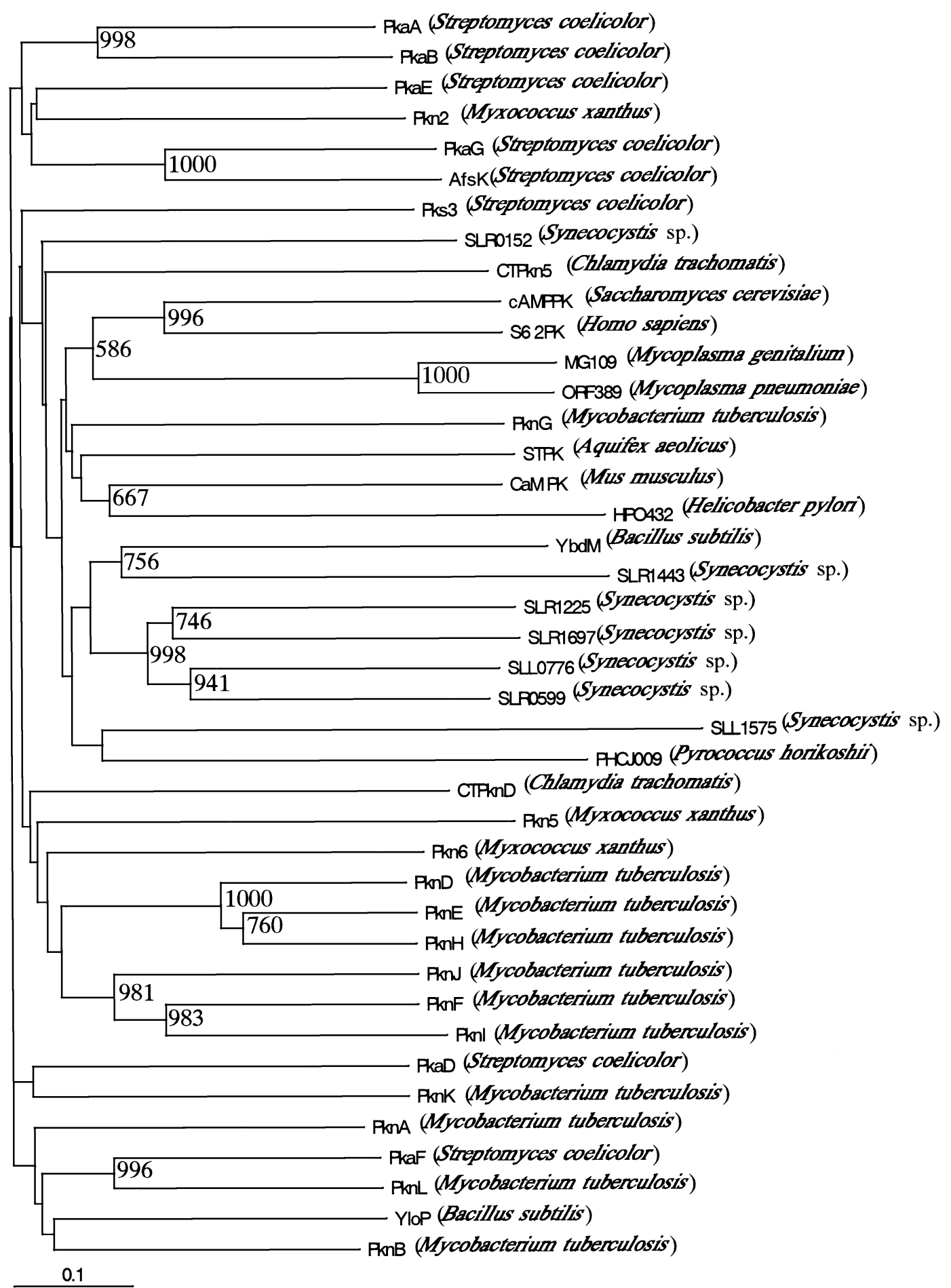

Fig. 7. Phylogenetic Tree Constructed on the Basis of Amino Acid Sequences of the Conserved Subdomains I-XI in 41 EukaryoticType Protein Kinases Using a Neighbor-Joining Method, Clustal W ${ }^{58}$ )

The numbers at the branch points are bootstrap probabilities. The scale-bar indicates 0.1 substitutions per site. The figure is cited from the reference. ${ }^{48)}$

し，多くの原核生物ではその生存に必要でなかった ために進化の過程で消失し，いくつかの細菌ではそ の必要性から保持してきたことを強く示唆してい る. またコドン利用性から判断して，S. coelicolor 由来の Pks3 や Synechocystis の SLL0776 は例外で
あり，近年，水平伝達によりほかの種から伝達され たことを㝝わせる結果である。

6. おわりに

以上，抗生物質をはじめとする多くの生理活性物 質を生産することで知られる放線菌において， $\beta-$ 
Table 6. Guanine + Cytosine Mole Percentage of Various Species and Protein Kinases

\begin{tabular}{|c|c|c|}
\hline Species & Protein kinase & $\begin{array}{l}\mathrm{G}+\mathrm{C} \% \text { in } \\
\text { coding region }\end{array}$ \\
\hline \multirow[t]{9}{*}{ S. coelicolor } & & 71.67 \\
\hline & PkaA & 75.51 \\
\hline & PkaB & 77.54 \\
\hline & PkaD & 74.81 \\
\hline & PkaE & 75.36 \\
\hline & $\mathrm{PkaF}$ & 73.26 \\
\hline & PkaG & 77.21 \\
\hline & AfsK & 76.31 \\
\hline & Pks3 & 65.31 \\
\hline \multirow[t]{4}{*}{ M. xanthus } & & 68.58 \\
\hline & Pkn2 & 71.45 \\
\hline & Pkn5 & 67.75 \\
\hline & Pkn6 & 68.17 \\
\hline \multirow[t]{2}{*}{ S. cerevisiae } & & 39.73 \\
\hline & сAMPPK & 40.96 \\
\hline \multirow[t]{2}{*}{ M. musculus } & & 52.76 \\
\hline & CaM_PK & 51.31 \\
\hline \multirow[t]{2}{*}{ H. sapiens } & & 52.85 \\
\hline & S6_2PK & 57.14 \\
\hline \multirow[t]{2}{*}{ H. pylori } & & 39.65 \\
\hline & HPO432 & 33.91 \\
\hline \multirow[t]{3}{*}{ B. subtilis } & & 44.32 \\
\hline & YloP & 44.24 \\
\hline & YbdM & 41.93 \\
\hline \multirow{2}{*}{ M. genitalium } & & 31.74 \\
\hline & MG109 & 32.61 \\
\hline \multirow[t]{2}{*}{ M. pneumoniae } & & 41.03 \\
\hline & ORF389 & 40.79 \\
\hline \multirow[t]{12}{*}{ M. tuberculosis } & & 65.81 \\
\hline & PknA & 67.75 \\
\hline & PknB & 63.31 \\
\hline & PknD & 65.31 \\
\hline & PknE & 65.72 \\
\hline & PknF & 67.58 \\
\hline & PknG & 66.13 \\
\hline & $\mathrm{PknH}$ & 66.93 \\
\hline & PknI & 67.35 \\
\hline & PknJ & 65.68 \\
\hline & PknK & 67.93 \\
\hline & PknL & 65.16 \\
\hline \multirow[t]{3}{*}{ C. trachomatis } & & 41.55 \\
\hline & CTPkn5 & 42.99 \\
\hline & CTPknD & 40.22 \\
\hline \multirow[t]{2}{*}{ A. aeolicus } & & 43.58 \\
\hline & STPK & 44.83 \\
\hline \multirow[t]{8}{*}{ Synechocystis sp. } & & 48.66 \\
\hline & SLL1575 & 49.76 \\
\hline & SLR1225 & 49.29 \\
\hline & SLR1443 & 50.98 \\
\hline & SLR1697 & 50.64 \\
\hline & SLR0152 & 49.34 \\
\hline & SLL0776 & 39.61 \\
\hline & SLR0599 & 54.45 \\
\hline \multirow[t]{2}{*}{ P. horikosii } & & 42.31 \\
\hline & PHCJ009 & 45.81 \\
\hline
\end{tabular}

ラクタムに対する自己耐性に関与している $\beta$-ラク タマーゼとペニシリン結合タンパク質の生化学と遺 伝子発現機構並びに病原菌において猛威を振るうこ れらタンパク質との関係と，二次代謝産物生合成の 遺伝子発現の調節に関与している真核生物型タンパ ク質キナーゼとを，分解と合成という観点から対比 して研究してきた結果の一端を述べた． $\beta$-ラクタ 厶関連の研究については一応の結論が得られたと思 うが，真核生物型タンパク質キナーゼの研究はこれ からプロテオーム解析などを十分に使いこなしてシ グナル伝達機構の全容を解明しなければならない. しかし，真核生物でもそうであるが，これらキナー ゼは一般に複雑に絡み合っており，1つを不活性化 してもほかのキナーゼが相補する可能性が高く，問 題を複雑にしている.いずれにしても, 近い将来シ グナル伝達機構の全貌が明らかになることを期待し たい.

本論文は, 私が 25 年間明治薬科大学薬学部生化 学教室において研究した成果を䌅めたものである.

この間のもう 1 つの大きな研究テーマとして, 制癌 剂をはじめとする新規生理活性物質の単離とその生 化学的研究がある。そのうち特にタンパク質チロシ ンキナーゼの特異的阻害物質としてのゲニステイン の発見 55,56$)$ ¿ AIDS 治療薬剂としての一連の物質 ${ }^{57)}$ は重要なものと位置づけているが，これらについて はここではふれなかった，現在の真核生物における 種々のシグナル伝達系の華々しい展開を見, 私ども のゲニステインに関する論文の引用を見るにつけ て，試薬としてのゲニステインが多少ともこのシグ ナル伝達系の解明に貢献できたのではないかと自負 している。また AIDS 治療薬剂の開発はヒューマ ンサイエンス振興財団のプロジェクトの一環として 行ったものであるが，実用にはならなかったとはい え財団から特に選ばれて SCID-Hu マウスの実験を 行っていただいた。有効な抗 AIDS 薬の開発を一 日も早く見たいものである.

謝辞 ここで述べた研究を行うに当たつては多く の共同研究者の協力なしには出来なかった．これら の方々の氏名は引用文献の著者以外にも多数ある. 名前を挙げて感謝の意を表したい。片山（西崎）博 子，嶋田（三好）佐知子，蓮見（清水）弥生，東恭 一郎の各氏にはスタッフとして主にスクリーニング 
で活躍していただいた。 また中野路子（現オクラホ マ大), 秋山徹 (現東大分生研教授) 両博士には助 手あるいは講師として教室の初期の基盤整備に多大 な努力を払っていただいた．私がここまで研究を推 進できたのも両氏に負うところが多い. また, 抗生 物質研究の手ほどきから始まり終始御指導, 御支援 下さった梅沢濱夫先生, 予研, 明治薬科大学での研 究の機会を与えて下さった水野伝一先生, 鈴木友二 先生に東心より感謝申し上げます。

これらの研究は文部省科学研究費のほか内藤記念 科学振興財団, 鈴木謙三研究財団, 日本私学振興財 団, Wacksman 財団をはじめとする多数の団体か らの御援助を戴き行われたものである。ここに記し て感謝申し上げます。また研究費を戴く際の多くの 方々の御支援にも，心より感謝申し上げます。

\section{REFERENCES}

1) Umezawa H., Mitsuhashi S., Hamada M., Iyobe S., Takahashi S., Utahara R., Osato Y., Yamazaki S., Ogawara H., Maeda K., J. Antibiotics, 26, 51-54 (1973).

2) Nagarajan R., In "Cephalosporins and Penicillins," ed. by Flynn E. H., Academic Press Inc., New York, 1972, pp. 636-661.

3) Ogawara H., Umezawa H., Biochim. Biophy. Acta, 327, 481-489 (1973) ; Ogawara H., Tanpakushitsu Kakusan Kouso, 20, 1214-1227 (1975). Ogawara H., Methods Enzymol., 46, 531-537 (1976); Ogawara H., Shimada S., Tanpakushitsu Kakusan Kouso, 22, 185-189 (1980) .

4) Ogawara H., Antimicrob. Agents Chemother., 8, 402-408 (1975).

5) Ogawara H., Horikawa S., Shimada-Miyoshi S., Yasuzawa K., Antimicrob. Agents Chemother., 13, 865-870 (1978).

6) Ogawara H., Kawamura N., Kudo T., Suzuki K., Nakase T., Antimicrob. Agents Chemother., 43, 3014-3017 (1999).

7) Ogawara H., In "Bioscience and Actinomycetes," ed. by Society for Actinomycetes Japan, Igaku Syuppan Center, Tokyo, 1994, pp. 132-143.

8) Ogawara H., The Actinomycetologist, 41, 2225 (1982)

9) Ogawara H., Mantoku A., Shimada S., J.
Biol. Chem., 256, 2649-2655 (1981).

10) Ogawara H., Horikawa S., J. Antibiotics, 32, 1328-1335 (1979).

11) Thompson S. T., Cass K. H., Stellwagen E., Proc. Natl. Acad. Sci. U.S.A., 72, 669-672 (1975) .

12 ) Matsubara - Nakano M., Kataoka Y., Ogawara H., Antimicrob. Agents Chemother., 17, 124-128 (1980).

13) Lenzini M. V., Nojima S., Dusart J., Ogawara H., Dehottay P., Frere J. M., Ghuysen J. M., J. Gen. Microbiol., 133, 2915-2920 (1987) .

14) Lenzini M. V., Ishihara H., Dusart J., Ogawara H., Joris B., Beeumen J. V., Frere J. M., Ghuysen J. M., FEMS Microbiol. Lett., 49, 371-376 (1988).

15) Urabe H., Lenzini M. V., Mukaide M., Dusart J., Nakano M. M., Ghuysen J.-M., Ogawara H., J. Bacteriol., 172, 6427-6434 (1990) .

16) Urabe H., Ogawara H., J. Bacteriol., 174, 2834-2842 (1992).

17) Bibb M. J., Findlay P. R., Johnson M. W., Gene, 30, 157-166 (1984).

18) Urabe H., Ogawara H., Actinomycetologica, 7, 65-67 (1993).

19) Urabe H., Ogawara H., Actinomycetologica, 10, 50-53 (1996).

20) Goethals K., van Montagu M., Holsters M., Proc. Natl. Acad. Sci. U.S. A., 89, 1646-1650 (1992).

21) Ogawara H., Actinomycetologica, 10, 104111 (1996); Ogawara H., Pharmacia, 33, 150154 (1997).

22) Urabe H., Toyama K., Ogawara H., J. Antibiotics, 43, 1483-1488 (1990).

23) Ogawara H., Gene, 124, 111-114 (1993).

24) Sendouda A., Urabe H., Ogawara H., FEMS Microb. Lett., 112, 343-348 (1993).

25) Kurai S., Urabe H., Ogawara H., Antimicrob. Agents Chemother., 39, 260-263 (1995).

26) Ogawara H., Katashiro Y., Higashi K., Urabe H., Actinomycetologica, 13, 82-88 (1999) .

27) Branlant G., Branlant C., Eur. J. Biochem., 150, 61-66 (1985).

28) Kushner D. J., Brevil C., Arch. Microbiol., 112, 219-223 (1977).

29) Jacobs C., Frere J.-M., Normark S., Cell, 88, 823-832 (1997); Jacobs C., Science, 278, 1731 -1732 (1997). 
30) Ogawara H., Mol. Phylogenetics Evol., 2, 97111 (1993).

31) Joris B., Ghuysen J.-M., Dive G., Renard A., Dideberg O., Charlier P., Frere J.-M., Kelly J. A., Boyington J. C., Moews P. C., Knox J. R., Biochem. J., 250, 313-324 (1987) .

32) Ogawara H., Kuma K., Miyata T., Microbiol. Immunol., 37, 399-403 (1993) .

33) Ogawara H., Horikawa S., Antimicrob. Agents Chemother., 17, 1-7 (1980).

34) Ogawara H., Horikawa S., J. Antibiotics, 33, 620-624 (1980); Horikawa S., Nakazawa H., Ogawara H., J. Antibiotics, 33, 1363-1368 (1980) ; Nakazawa H., Horikawa S., Ogawara H., J. Antibiotics, 34, 1070-1072 (1981).

35) Ogawara H., Microbiol. Reviews, 45, 591-619 (1981).

36) Hao J., Kendrick K. E., J. Bacteriol., 180, 2125-2132 (1998); Hao J., Kendrick K. E., J. Bacteriol., 182, 5521-5529 (2000).

37) Parkinson J. S., Kofoid E., Annu. Rev. Genet., 26, 71-112 (1972).

38) Hunter T., Cooper J. A., Annu. Rev. Biochem., 54, 897-930 (1985); Hanks S. K., Quinn M., Hunter T., Science, 241, 42-52 (1988) .

39) Koshland Jr. D. E., Science, 262, 532 (1993).

40) Munoz-Dorado J., Inouye S., Inouye M., Cell, 67, 995-1006 (1991).

41) Urabe H., Ogawara H., Gene, 153, 99-104 (1995) .

42) Ogawara H., Urabe H., Ohtaki R., Nakamura Y., J. Bacteriol., 177, 5342-5345 (1995).

43) Curran J. F., Yanus M., J. Mol. Biol., 203, 75 -83 (1988).

44) Atkins J. F., Weiss R. B., Gesteland R. F., Cell, 62, 413-423 (1990).

45) Horinouchi S., Actinomycetologica, 7, 68-87 (1993) .

46) Ogawara H., GenBank Accession Number AB019513.

47) Urabe H., Bibb M., Ogawara H., submitted.
48) Ogawara H., Aoyagi N., Watanabe M., Urabe H., Microbiology, 145, 3343-3352 (1999) .

49) Ogawara H., Actinomycetologica, 13, 1-8 (1999).

50) Zhang C. C., Mol. Microbiol., 20, 9-15 (1996).

51) Pearson W. R., Lipman D. J., Proc. Natl. Acad. U.S.A., 85, 2444-2448 (1988).

52) Felsenstein J., Phylip, Version 3.5c, University of Washington, U.S.A., 1995.

53) Ina Y., DDBJ, National Institute of Genetics, 1991.

54) Adachi J., Hasegawa M., Computer Science Monographs No. 27, Institute of Statistical Mathematics, Tokyo, 1992.

55) Ogawara H., Akiyama T., Ishida J., Watanabe S., Suzuki K., J. Antibiotics, 39, 606-608 (1986).

56) Akiyama T., Ishida J., Nakagawa S., Ogawara H., Watanabe S., Itoh N., Shibuya M., Fukami Y., J. Biol. Chem., 262, 55925595 (1987); Akiyama T., Ogawara H., Methods Enzymol., 201, 362-370 (1991); Akiyama T., Ogawara H., In "Protein Phosphorylation,” ed. by Sefton B. M., Hunter T., Academic Press Inc., New York, 1998, pp. 553 -561 .

57) Nakashima H., Ichiyama K., Hirayama F., Uchino K., Ito M., Saitoh T., Ueki M., Yamamoto N., Ogawara H, Antiviral Research, 30, 95-108 (1996); Ueki M., Watanabe S., Ishii Y., Okunaka S., Uchino K., Saitoh T., Higashi K., Yamamoto N., Nakashima H., Ogawara H., submitted; Ueki M., Watanabe S., Saitoh T., Yamamoto N., Nakashima H., Ogawara H., submitted.

58) Thompson J. D., Higgins D. G., Gibson T. J., Nucleic Acids Res., 22, 4673-4680 (1994).

59) Kieser T., Bibb M. J., Buttner M. J., Chater K. F., Hopwood D. A., In "Practical Streptomyces Genetics," The John Innes Foundation, Norwich, 2000. 